\title{
Empirical Investigation of the Effect of Amenities and Other Factors on Business Location Decisions
}

by F.J. Calzonetti* and T. Allison

Economics and Law Section,

Environmental Assessment and Information Sciences Division,

Argonne National Laboratory, 9700 South Cass Avenue, Argonne, Illinois 60439

November 1992 (printed February 1993)

Work sponsored by United States Department of Energy, Office of Civilian Radioactive Waste Management

"Calzonetti is affiliated with West Virginia University, Morgantown, West Virginia. 


\section{CONTENTS}

EXPLANATION OF TERMS $\ldots \ldots \ldots \ldots \ldots \ldots \ldots \ldots \ldots \ldots \ldots$ vi

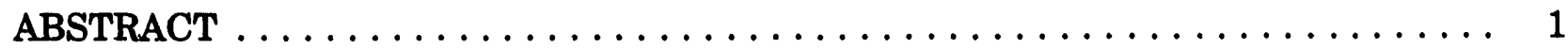

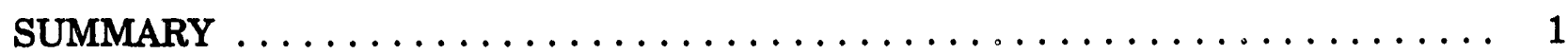

$1 \quad$ INTRODUCTION $\ldots \ldots \ldots \ldots \ldots \ldots \ldots \ldots \ldots \ldots \ldots \ldots \ldots \ldots$

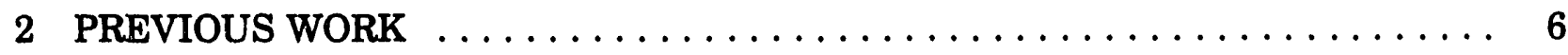

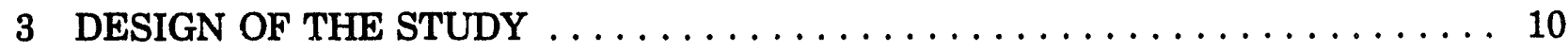

3.1 Manufacturing Establishment Survey $\ldots \ldots \ldots \ldots \ldots \ldots \ldots \ldots \ldots$

3.2 Producer Service Establishment Survey $\ldots \ldots \ldots \ldots \ldots \ldots \ldots \ldots \ldots$

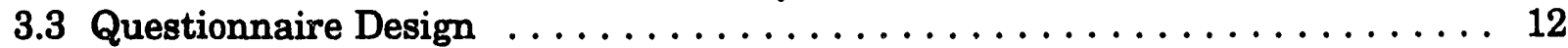

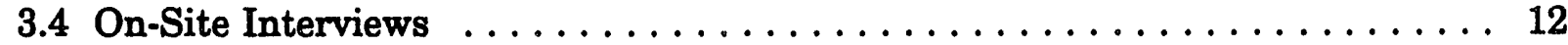

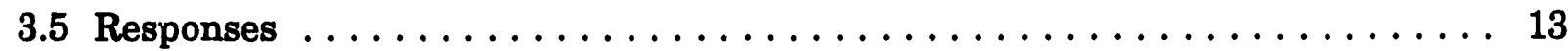

4 CHARACTERISTICS OF RESPONDENTS $\ldots \ldots \ldots \ldots \ldots \ldots \ldots \ldots$

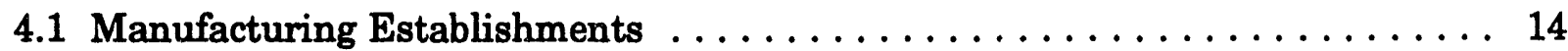

4.2 Producer Service Establishments . . . . . . . . . . . . . . . . . . 14

5 IMPORTANCE OF AMENITIES AS A BUSINESS LOCATION FACTOR . . . . . . 17

5.1 Manufacturing Establishments $\ldots \ldots \ldots \ldots \ldots \ldots \ldots \ldots \ldots \ldots \ldots$

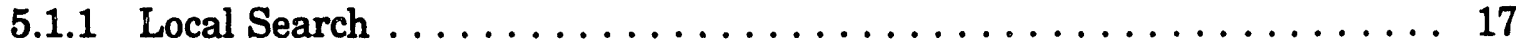

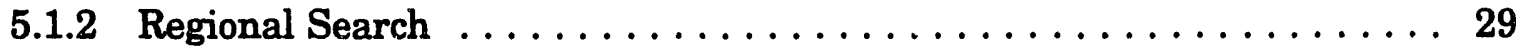

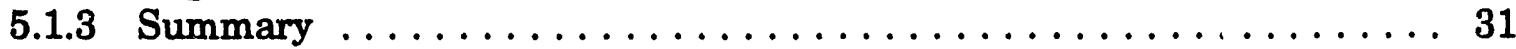

5.2 Producer Service Establishments $\ldots \ldots \ldots \ldots \ldots \ldots \ldots \ldots \ldots \ldots \ldots \ldots \ldots$

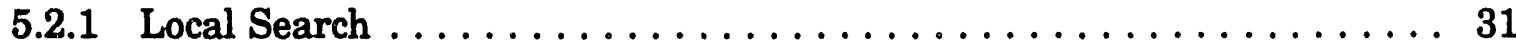

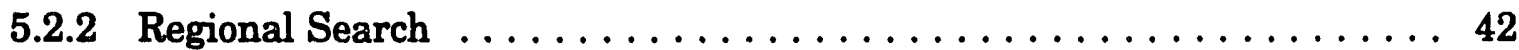

5.2 .3 Summary $\ldots \ldots \ldots \ldots \ldots \ldots \ldots \ldots \ldots \ldots \ldots \ldots \ldots \ldots \ldots$

6 SUMMARY OF FINDINGS AND IMPLICATIONS FOR HIGH-LEVEL WASTE STORAGE AND DISPOSAL PROGRAMS $\ldots \ldots \ldots \ldots \ldots \ldots \ldots$

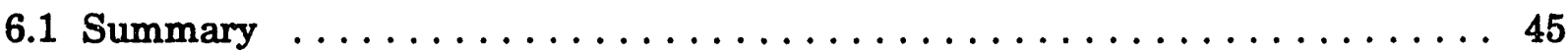

6.2 Implications $\ldots \ldots \ldots \ldots \ldots \ldots \ldots \ldots \ldots \ldots \ldots \ldots \ldots \ldots \ldots \ldots \ldots$

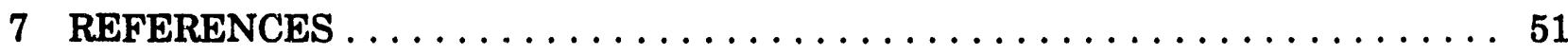

APPENDIX: Manufacturing Establishment Survey Questionnaire . . . . . . . 55 


\section{TABLES}

1 Distribution of Respondents to Manufacturing Establishment Survey, by Standard Industrial Classification Code $\ldots \ldots \ldots \ldots \ldots \ldots \ldots \ldots \ldots$

2 Number of Respondents to Manufacturing Establishment Survey and Producer Service Establishment Survey $\ldots \ldots \ldots \ldots \ldots \ldots \ldots \ldots \ldots$

3 Number of Respondents to Manufacturing Establishment Survey, by Establishment Type and Size $\ldots \ldots \ldots \ldots \ldots \ldots \ldots \ldots \ldots \ldots \ldots$

4 Number of Respondents to Producer Service Establishment Survey,

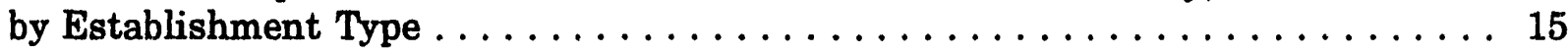

5 Number of Respondents to Producer Service Establishment Survey,

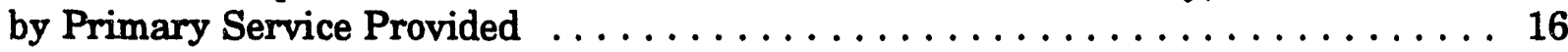

6 Ranking of Factors Considered in Local Search by All Manufacturing

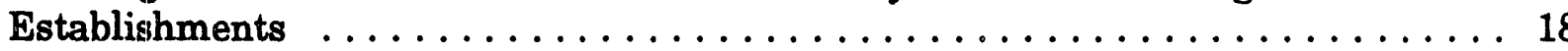

7 Ranking of Factors Considered in Local Search by Single-Location

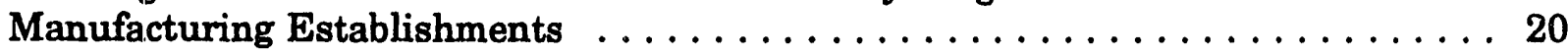

8 Ranking of Factors Considered in Local Search by Branch Establishments of Multilocation Manufacturing Firms $\ldots \ldots \ldots \ldots \ldots \ldots \ldots \ldots \ldots \ldots \ldots$

9 Ranking of Factors Considered in Local Search by Smaller Manufacturing Establishments

10 Ranking of Factors Considered in Local Search by Larger Manufacturing

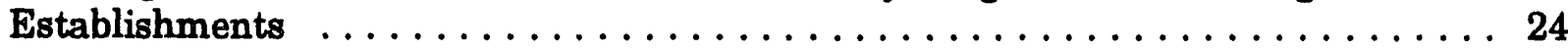

11 Ranking of Factors Considered in Local Search by Smaller Single-Location

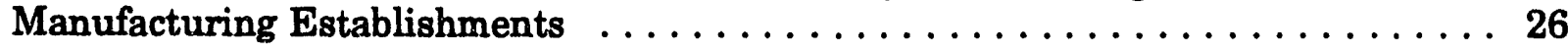

12 Ranking of Factors Considered in Local Search by Larger Branch Establishments of Multilocation Manufacturing Firms $\ldots \ldots \ldots \ldots \ldots \ldots 27$

13 Ranking of Factors Considered in Regional Search by All Manufacturing

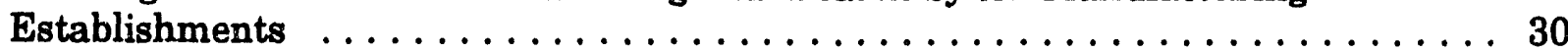

14 Ranking of Factors Considered in Local Search by All Producer Service Establishments 


\section{TABLES (Cont.)}

15 Ranking of Factors Considered in Local Search by Smaller Producer Service

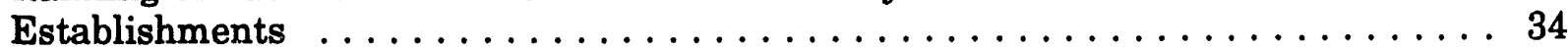

16 Ranking of Factors Considered in Local Search by Larger Producer Service Establishments .............................. 35

17 Ranking of Factors Considered in Local Search by Headquarters Establishments of Multilocation Producer Service Firms $\ldots \ldots \ldots \ldots \ldots \ldots$

18 Ranking of Factors Considered in Local Search by Single-Location Producer Service Establishments $\ldots \ldots \ldots \ldots \ldots \ldots \ldots \ldots \ldots \ldots \ldots \ldots$

19 Ranking of Factors Considered in Local Search by Branch Establishments of Multilocation Producer Service Firms . . . . . . . . . . . . . . . . . 39

20 Ranking of Factors Considered in Local Search by Larger Branch Establishments of Multilocation Producer Service Firms .............. 40

21 Ranking of Factors Considered in Regional Search by All Producer Service Establishments ............................... 


\section{EXPLANATION OF TERMS}

Some of the specialized terms that appear in this report are described here.

A business or firm (used interchangeably) refers to an organization in any sector of the economy not involving a government or other public-sector institution. These sectors include agriculture, durable and nondurable manufacturing, transportation and public utilities, wholesaling and retailing, and business services. Business activities refer to the activities undertaken by a business or firm. An establishment is an individual unit of a firm. Manufacturing establishments manufacture products; producer service establishments provide services, primarily to other firms.

Some firms carry out their production, administrative, sales, and managerial activities at a single location; establishments of these firms are called single-location establishments. Other firms have establishments at more than one location. Establishments specializing in routine production or service activities are called branch establishments of multilocation firms. Establishments specializing in managerial and other control activities are called headquarters establishments.

Amenities (or amenity factors) are any positive (or beneficial) qualities or features that encourage a firm to choose a particular location for a business establishment. Amenities can be features of specific man-made objects, like houses or cars. In this report, however, amenities refer to environmental amenities, which are described more fully in the next paragraph. Disamenities (or disamenity factors) are negative qualities or features that influence a firm not to choose a particular location. An example of a disamenity is any risk perception that might be associated with the siting of a nuclear facility. The risk perception could be held by a potential host community or by a business decision maker searching for a location. Nonamenity factors are all other economic factors that might affect a business location decision, such as proximity to product or labor markets.

Environmental amenities are aspects of the natural (i.e., physical) and cultural environment that help firms choose among potential business locations. The natural and cultural environment can include specific amenities or simply represent the general level of amenity provided in an area. Natural amenities include lakes, mountains, state parks and other recreational areas, and fishable waters. The majority of cultural amenities are more urban in character. Examples are concert halls, sports facilities, libraries, art galleries, theaters, museums, and parks. 


\title{
EMPIRICAL INVESTIGATION OF THE EFFECT OF AMENITIES AND OTHER FACTORS ON BUSINESS LOCATION DECISIONS
}

by

\author{
F.J. Calzonetti and T. Allison
}

\begin{abstract}
The impacts that risk perceptions have on those deciding whether to locate a business activity in an area likely to host a nuclear waste facility have become an important consideration in analyses that deal with choosing a site for nuclear waste facilities. This report presents empirical evidence on the importance of environmental amenities and disamenities in business location decisions gathered from surveys and interviews of owners and managers of manufacturing and producer service establishments in Colorado and Utah. Results show that amenities are a much more important consideration for producer service establishments than for manufacturing establishments. Policies of host communities to offset the loss of business establishments that could result from risk perceptions associated with nuclear waste facilities should therefore take into account how sensitive the business activities that are present or likely to locate in the area are to environmental amenities.
\end{abstract}

\section{SUMMARY}

This report discusses an empirical investigation of the importance of amenities and other factors in business location decisions. It also provides information on how the perceived risks associated with disamenities affect existing and future decisions to locate business facilities. The report will therefore provide valuable information to the Office of Civilian Radioactive Waste Management (OCRWM) in the U.S. Department of Energy (DOE), since it has been suggested that locating the DOE repository at Yucca Mountain in Nevada or monitored retrievable storage facilities elsewhere could significantly alter the perceptions firms have of these areas as prospective locations for new and expanded business establishments. Consequently, the ability of communities that might host nuclear waste facilities to pursue economic development strategies that were based on a consideration of manufacturing and service activities unrelated to the nuclear waste facilities might also change.

The aim of this report is to provide specific information on the magnitude of the impacts of nuclear waste facilities on business location decisions. It presents new information on the importance of specific natural and cultural amenities in decisions to choose new 
locations. The report deals not only with manufacturing establishments but also with establishments that provide business services to other establishments (producer service establishments). It also includes information on how important amenities are when a firm is deciding whether to maintain an establishment at an existing location and how important risk perceptions are when a firm is deciding whether to move an establishment to an alternative location.

This report has six sections. Section 1 is an introduction, and Section 2 is a summary of findings in the academic literature. Section 3 outlines the design of the study and describes the structure and content of the two telephone surveys used to collect information from establishments in Colorado and Utah. These states were chosen for the following reàsons:

- They have a variety of cultural, recreational, physical, and environmental amenities.

- They compete with Nevada as sites for firms considering locations for new or expanded establishments.

- They have diverse economic bases and are made up of cities and communities in a wide range of sizes.

- There are data sources on both manufacturing and producer service establishments for both states.

The telephone surveys considered 27 location factors categorized into six major groups: (1) labor (cost and quality), (2) communications, (3) market access, (4) taxes, (5) incentives to new businesses, and (6) amenities (including natural fearures, cultural and recreational facilities, environmental quality, and other indices of quality of life).

Section 4 outlines the characteristics of the manufacturing and producer service establishments that responded to the telephone questionnaires. Respondents are described according to the nature of their product or service, size of establishment, and type of establishment (e.g., headquarters establishment, single-location establishment, branch establishment of a multilocation firm, or sales office).

Section 5 begins by summarizing the results of the telephone surveys. It provides information on the sipnificance of amenities to manufacturing and producer service establishments and compares amenities with other factors that influence location decisions. It describes, for both types of establishments, the factors that are important in choosing a location at both the local and regional level. Section 5 also assesses how the importance of various location factors differs, depending on the size of the establishment and on whether the establishment is a single-location establishment or branch establishment of a larger firm. In addition, Section 5 presents the results of on-site interviews conducted with a small sample of establishments that indicated in the telephone surveys that amenities had been a significant consideration in their initial location choice or their decision to remain at their 
existing location. Results of the interviews show not only that amenities are important in the initial location decision but also that significant or unexpected changes in local amenities are likely to cause firms to reevaluate locations of existing establishments. The report also shows that amenities are not as important to manufacturing establishments as they are to producer service establishments (which listed amenities as being a dominant factor when they were selecting a location). Therefore, a loss of amenities or the development of significant disamenities in an area could affect the ability of that area to attract certain types of business activities.

Section 6 summarizes the findings of the empirical work and outlines the implications of these findings for high-level waste disposal programs. While the results of the surveys showed that amenities were more important to certain types of business activity than others, the interviewees in this study did not seem to be too concerned about nuclear waste facilities at their present location or about whether these facilities had or would lead to the relocation of business activities elsewhere. Despite this relative unconcern, it is still important that the development of nuclear waste facilities be carefully planned and executed so the attractiveness of nearby local communities can be maintained. 


\section{INTRODUCTION}

This report describes and discusses an empirical investigation of the importance of amenities and other factors in business location decisions. The study also explores, in much less detail, how any risk perceptions (a disamenity) associated with nuclear waste facilities can affect existing and future business location decisions and how the introduction of a nuclear waste facility to an area can cause firms to seek to move business activities elsewhere. This information should be of interest to the Office of Civilian Radioactive Waste Management (OCRWM) in the U.S. Department of Energy (DOE), since locating the new DOE high-level radioactive waste repository at Yucca Mountain in Nevada - or locating monitored retrievable storage (MRS) facilities elsewhere - could alter the host state's or host community's ability to attract new establishments or retain existing establishments because of the consequent reduction in the level of amenities in the area.

This report provides new empirical information on how important natural and cultural amenities are to both manufacturing and producer service establishments that are choosing a new location, and it explores the importance of amenities and disamenities to businesses that are deciding whether to remain at their existing location. Although the literature on locating businesses has shown that amenities are of some importance to a business that is choosing a location for a new establishment, the empirical work discussed in this literature has not explored amenity factors in great detail, and most of the work has concentrated on manufacturing establishments. In addition, it has not expended much effort in identifying specific amenities of interest to the business-location decision maker.

The report summarizes information collected from telephone and on-site interviews of manufacturing and producer service establishments in Colorado and Utah. These states were selected because they are rich in environmental amenities and compete with Nevada as sites for firms that are considering opening or expanding. Both states also have large cities as well as small communities and diverse industrial bases. 


\section{PREVIOUS WORK}

The role of amenities as a factor influencing business location decisions is reviewed in two other Argonne National Laboratory reports (Allison and Calzonetti 1990; Allison 1991), so a complete literature review is not presented here. Traditionally, amenities have not been considered a major factor affecting business location decisions. In most research on how industries choose locations, investigators have focused attention on labor, land, transportation, and other factors that directly relate to the cost of opening or operating a business. Although amenity factors were shown to be an important consideration in business location decisions as early as 1949 (McLaughlin and Robock 1949), most work has not clarified the meaning of amenities beyond residual or personal factors. In recent years, however, amenity factors could not be ignored, even in studies investigating firms totally devoted to manufacturing. The significance of amenities has been rising in many studies, and regional and local amenity factors are often promoted by planners and local authorities as a means of attracting new industries (Smith 1971; Kale and Lonsdale 1979; Burgess 1982; Ballard and James 1983; Raitz 1988; Keeble 1989). Despite the recent recognition that amenities are an important factor in making an area attractive to business, there has been less empirical work done with regard to this topic than the traditional factors mentioned above. Also, there has not been a great deal of effort to accurately describe amenities and how they can influence the location of various types of establishments.

Some industry location studies focus on regional factors; others investigate local factors. At the regional level, studies of the importance of amenities are often limited by the type of data available to represent the level of amenities at a particular location. Because of this limitation, climatic variables are most frequently used. Many studies, for example, note that part of the reason for the growth of the Sunbelt was that businesses were seeking better environmental conditions than those found in the Northeast. Many regional studies, because of the lack of plant-level data, use regional industrial growth variables (such as changes in employment growth across industrial sectors) as proxies for trends in the location of individual manufacturing and business service establishments (Wheat 1973, 1986; Keeble 1980; Plaut and Pluta 1983). At the metropolitan level, access to recreational amenities has been considered a factor in the growth of office space and employment (Ihlanfeldt and Raper 1990). Although results from these studies show that amenities are somewhat significant factors in both industrial and office growth, some doubt must be cast on the validity of the results for policy analysis, given the often proxy nature of the variables chosen.

At the local level, amenities become closely intertwined with "hometown" considerations. It is quite common for survey-based studies to find "hometown" as the dominant location factor for small businesses. For instance, a survey of more than 800 manufacturing establishments conducted by Urban Systems Research and Engineering, Inc. (1974), showed that locally owned firms usually locate establishments in communities to which the owners have personal attachments. Almost all of the smallest establishments surveyed were located where the company owner lived when the business was started. Surveys of new firms in Pennsylvania and Minnesota indicated that new firms are started 
by people who live in the area, not by people moving into the area (Reynolds and Freeman 1987; Reynolds and Miller 1987). However, in interviews, many business owners indicated that if their hometown offered a "good quality of life" and were rich in amenity values, they would return to start businesses.

More meaningful analyses of the role of amenities in industrial location decisions would place them within the broader contexts of changes in the orientation of the U.S. economy toward light manufacturing and business services and of changes in the spatial organization of firms. These changes have placed a different emphasis on the factors that are important to the location of industries. In many cases, manufacturing and business service firms have become more flexible regarding the location of material inputs, and changes in transportation technology and telecommunications have reduced the costs of marketing many manufactured goods and business services. As a result, labor costs have often emerged as the single most important factor in determining the location of new industrial activities. Increased locational flexibility has allowed many firms, especially large corporations, to separate specific activities (such as headquarters, research and development facilities, support services, sales offices, and production facilities) and choose cost-minimizing locations for each activity on the basis of a consequently smaller number of minimum locational requirements. Accordingly, separate activities have developed their own locational patterns.

Corporate headquarters and other high-level business services (e.g., finance, insurance, legal, advertising, and consulting services) have located in the centers of a small number of large cities. The economics of agglomeration dominates the location choices of headquarters and their associated service functions, particularly the need to minimize the costs of face-to-face contact between high-level executives. Nonetheless, part of the decision of where to locate headquarters facilities may be based on amenities found in metropolitan areas. For example, Schmenner (1982) surveyed several corporate headquarters in New England to establish which factors had been important in site selection. Schmenner found that when a choice was being made among regions, markets and labor (wages and labor skills) were most frequently ranked as important; amenities (aesthetic qualities) were important to only a small proportion of the respondents. However, when firms were required to choose specific sites for establishments at the local level, amenities were more important. Burns and Pang (1977) found that amenities were important to all 38 headquarters facilities that were surveyed in their decisions to relocate corporate headquarters from one central city location to another and from a central city location to a suburban location. In particular, cultural attractions, university facilities, entertainment, and residential environments were found to be important amenities. Firms involved in research and development also tend to be located at the peripheries of large urban centers, where the availability of scientific and technical labor and proximity to headquarters facilities are the most important location factors (Malecki 1989).

A limited amount of evidence has been collected on the role of amenities in the choice of locations for office activities in general, as distinct from corporate headquarters functions. Rhodes and Kan (1971), for example, conducted a survey of 60 commercial offices that had 
moved from central London, either partially or completely. The managers surveyed placed a high value on the quality of the area surrounding their new location, particularly its lack of a manufacturing base or the likelihood of one developing in the future.

Other establishments have been located in more peripheral areas and may not be influenced by locational amenities. The routine manufacturing branch establishments of larger corporations, for example, are often located on the basis of geographic variations in production labor costs, with local material and information linkages and costs of product transportation being relatively unimportant (Kale and Lonsdale 1979). Also, smaller communities may have a large number of skilled, nonmilitant workers with a strong work ethic, and they may offer low land costs and low taxes (Hart 1988). McLaughlin and Robock (1949) found that firms would locate manufacturing establishments in a small town to avoid strong labor competition. Simiiarly, the location of routine data processing and other "back office" activities often follows a similar pattern, with labor costs being the primary locational determinant. Often the activities or functicns at these locations are tied to other corporate locations by means of telecommunications links, through which relevant inputs and outputs are sent and received (Moss and Dunau 1986).

For smaller manufacturing firms, the importance of amenities seems to vary according to the spatial scale at which the location decision is made. Spooner (1973), in a survey of key workers and managers in industrial establishments that had moved into southwestern Great Britain, found amenity factors to be more important in a regional search for a location for a new establishment than in a local search. Stafford (1974), in a survey of manufacturing relocation in Ohio, found that firms conducting a regional search placed more emphasis on amenities when choosing a new location for an establishment than did those conducting a local search. For firms conducting a local search, amenities were not as important as traditional factors such as personal contacts, labor factors, transportation, and markets. Amenities specifically installed to attract new establishments were not found to be significant.

Smaller business service firms, on the other hand, can usually consider more locations than can manufacturing firms, and, in some cases, they place more emphasis on amenities. Improvements in telecommunications and the growth of contact networking have allowed more of the larger manufacturing and service firms to subcontract services to smaller firms, which allows the larger firms to locate establishments in peripheral areas that may be richer in amenities.

Structural changes have also been accompanied by significant shifts in the occupational structure of employment, with a larger proportion of the manufacturing labor force now involved in service occupations rather than occupations directly associated with production. Significant growth has also occurred in independent business service firms. The separation of activities within many firms and the specialization of functions at each location have led to a spatial division of labor, with different functions supporting specialized occupations at different locations. Hall et al. (1987) found that the importance of amenities depends on the type of firm. In locating establishments likely to require a highly educated 
labor force, decision makers often give careful consideration to the level of amenities. This situation has been true for high-tech manufacturing and service-related activities, including electronic data processing, telecommunications, and consulting services (McGregor et al. 1986; Makusen et al. 1986; Hall et al. 1987). Favorable housing costs and availability, cultural and recreational facilities, pleasant environment, and social relations with others in the same industry were much more significant for branch establishments of multilocation and multinational firms than for single-location establishments.

Amenities may also be important to the success of office-based firms that need to recruit and maintain staff at new and existing locations. Pacione (1982) considered the effect of residential desirability on interregional office relocation decisions. He found culiural and recreational amenities to be an important part of the decision to choose a new office location. Ley (1985) assessed how amenities affect employee satisfaction at two metropolitan locations, one downtown and one suburban. Cultural and recreational amenities were found to be a more important consideration at the downtown location; environmental amenities were more important at the suburban location.

It therefore appears that a sensitivity to environmental considerations, cultural and recreational amenities, and quality of life in general become important to some firms and for certain business activities when a location is being chosen. 


\section{DESIGN OF THE STUDY}

This study uses information collected in telephone surveys by the West Virginia University Survey Research Center (WVUSRC) and selected on-site interviews with owners, plant managers, and other representatives of manufacturing and producer service establishments in the states of Colorado and Utah. These two states were selected for several reasons.

First, it was decided to collect information from states similar in many ways to Nevada to provide better information on factors that might be of interest to new or existing Nevada businesses. Therefore, states with a high level of environmental amenities, such as sunshine, parks and recreation areas, hunting and fishing, and mountains, were targeted. States with urban congestion problems (e.g., California) were not targeted, since information from other sources suggested that some establishments located in Nevada to escape such disamenities. The above criteria helped narrow the search to the Rocky Mountain-Great Basin states. The Rocky Mountain-Great Basin states have environmental amenities similar to those of Nevada, and urban congestion was a factor in these states only in certain areas.

Second, because it had been decided to conduct a survey of both manufacturing and producer service establishments, it was necessary to select states that had listings for both types of establishments. Colorado and Utah have manufacturing plant directories with information on the locations and standard industrial classification (SIC) codes of the establishments. Both states also have chamber of commerce directories for cities with populations of more than 10,000 . The directories have information on producer service establishments that covers type of service provided, addresses, and telephone numbers. The samples of manufacturing and producer service establishments were drawn solely from locations listed in a chamber of commerce directory.

\subsection{MANUFACTURING ESTABLISHMENT SURVEY}

The manufacturing establishment survey used the Colorado and Utah manufacturing directories for sampling frames. Table 1 shows the distribution across SIC codes of the 3,982 establishments in Colorado and Utah that were selected by using this approach. More than $20 \%$ of the manufacturing establishments in both Colorado and Utah are in printing and publishing (SIC 27), and more than $10 \%$ of the establishments deal with machinery, except electrical (SIC 35). Some SIC categories such as textile mills (SIC 22) were expected to be underrepresented in these states. However, to gain information from a wide cross section of industries, an adjustment was made to increase the probability that more establishments in the underrepresented industries would be selected for the survey. The final distribution across industrial classifications was based upon this adjusted sample; however, because of the variation in the cooperation level and the number of successful contacts, there was still a nonuniform distribution of responses across SIC codes. Nonetheless, no one industry represented more than $10 \%$ of the total sample, and responses were gathered from all manufacturing SIC codes. 


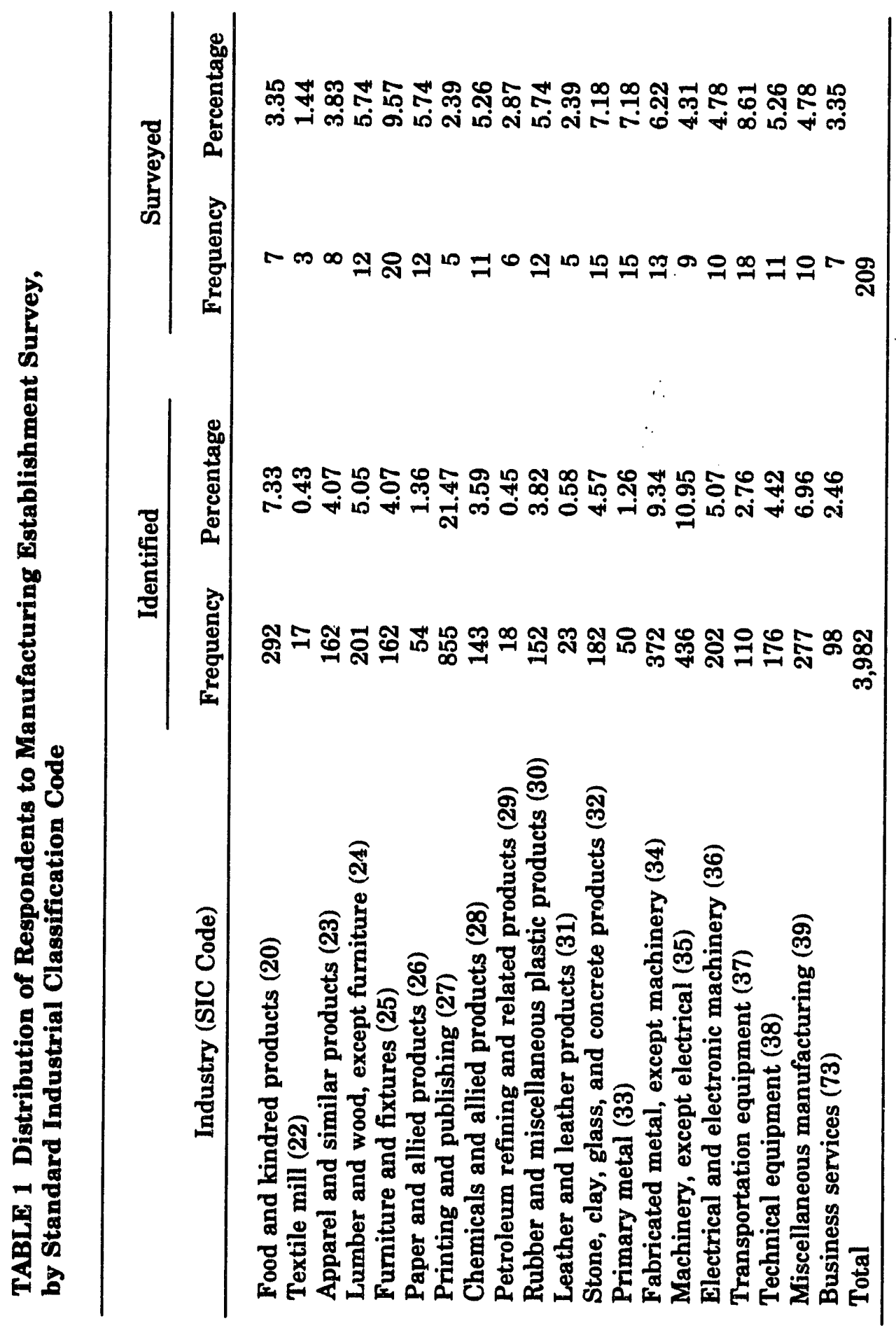




\subsection{PRODUCER SERVICE ESTABLISHMENT SURVEY}

The sample of producer service establishments was selected from chamber of commerce listings for locations in Colorado and Utah. One of the concerns of this survey was to correctly target producer service establishments that direct their sales to businesses rather than consumers. To accomplish this, the first question asked of the producer service establishment was, "Over the past three years, did sales to other businesses account for, on average, more than 50\% of your total sales?" If the respondent said "yes" to this question, the interview continued, and the establishment was included in the producer service establishment survey.

\subsection{QUESTIONNAIRE DESIGN}

The two questionnaires were designed for telephone interviews. (The questionnaire for the marufacturing establishment survey is shown in the appendix.) The questionnaires for the manufacturing and producer.service establishments differed to account for the broad differences between these two sectors. The questionnaires were designed in consultation with the WVU SRC and external experts in the field of locating manufacturing and producer service establishments. The questionnaires contained sections on (1) factors important to a firm in evaluating which region of the country in which to locate an establishment and (2) factors important to a firm in comparing two or more localities within a particular region. The questionnaires also covered the use of business services, occupational categories of the employees, and destinations for final sales. Finally, they contained specific questions about the size and nature of the firm (e.g., ownership).

\subsection{ON-SITE INTERVIEWS}

To confirm the results of the telephone survey, provide additional information about the operating history of selected plants, and supply more details about the concerns that managers and owners had about amenities and disamenities, selected on-site interviews were conducted during the fall and winter of 1991. The establishments interviewed were selected from among those establishments that had noted amenities as having been an important factor in a location decision. Eight establishments in Utah (six manufacturing and two producer service establishments) and six establishments in Colorado (two manufacturing and four producer service establishments) were visited. Each interview lasted about one hour. In the structured interview, the questionnaire was reviewed and then the interviewee was asked questions related to the location decision, that is, the importance of amenities, concerns about disamenities or noxious facilities, and the importance of these factors to the establishment's employees. 


\subsection{RESPONSES}

As indicated in Table 2, a total of 545 manufacturing establishments and 578 producer service establishments were contacted by the WVU SRC during the survey period (summer 1991). Many of the establishments initially contacted for the manufacturing survey were eliminated -13 had been in correctly classified as manufacturers, 51 had disconnected telephones, 141 could not be contacted, and 131 refused to participate. Thus, 209 manufacturing establishments completed the survey, yielding a response rate of $31.8 \%$. In the case of the producer service establishments, of the 578 establishments contacted, 23 were deleted because of incorrect classification, 46 because of disconnected telephones, 171 because they could not be cuntacted, and 124 because they refused to participate. Therefore, 214 producer service establishments completed the survey, yielding a response rate of $42.1 \%$.

TABLE 2 Number of Respondents to Manufacturing Establishment Survey and Producer Service Establishment Survey

\begin{tabular}{lcc}
\hline Respondent Category & $\begin{array}{c}\text { Number of } \\
\text { Manufacturing } \\
\text { Establishments }\end{array}$ & $\begin{array}{c}\text { Number of } \\
\text { Producer Service } \\
\text { Establishments }\end{array}$ \\
\hline Total contacted & 545 & 578 \\
Deleted $^{\mathrm{a}}$ & 13 & 23 \\
Disconnected telephones $_{\text {Contacts unavailable }}$ & 51 & 46 \\
Refusals & 141 & 171 \\
Completed questionnaires & 131 & 124 \\
& 209 & 214 \\
Response rate $(\%)^{\mathrm{b}}$ & 31.8 & 42.1 \\
\hline
\end{tabular}

a Establishments that were incorrectly classified as manufacturers or producer services.

b Total contacted minus those deleted and those having disconnected telephones, divided by the total number that completed the questionnaires. 


\section{CHARACTERISTICS OF RESPONDENTS}

This section of the report summarizes the characteristics of the establishments that responded to the questionnaire. The characteristics of the manufacturing establishments are provided first; information about the producer service establishments follows.

\subsection{MANUFACTURING ESTABLISHMENTS}

A total of 209 manufacturing establishments responded to the questionnaire. Table 3 lists the respondents according to type of plant (single-location establishment or branch establishment). Of the total, 179 (86\%) were single-location establishments, and 28 (13\%) were branch establishments. Table 3 also shows the size distribution of the respondents within these two categories. Of the 207 establishments for which information was available, $125(60 \%)$ had fewer than 20 employees and $82(40 \%)$ had 20 or more employees. Not surprisingly, larger establishments were better represented in the branch establishments than the single-location establishments. More than $71 \%$ of the branch plants had 20 or more employees. By contrast, $71.5 \%$ of the single-location establishments had fewer than 20 employees.

\subsection{PRODUCER SERVICE ESTABLISHMENTS}

Table 4 provides a categorized listing of the producer service establishments. Of the 214 producer service establishments, 128 (about 60\%) were single-location establishments. Forty-eight (22\%) were branch establishments of multilocation producer service firms, and $31(14.5 \%)$ were headquarters establishments of multilocation producer service firms. Thus, these three categories accounted for almost $97 \%$ of the total responses. Four establishments were regional or local sales offices; one was a data entry or data processing office; and one was a service establishment of a manufacturing firm.

TABLE 3 Number of Respondents to Manufacturing Establishment Survey, by Establishment Type and Size

\begin{tabular}{|c|c|c|c|}
\hline Establishment Type & $\begin{array}{l}\text { Number with } \\
\text { Fewer than } \\
20 \text { Employees }\end{array}$ & $\begin{array}{l}\text { Number with } \\
20 \text { or More } \\
\text { Employees }\end{array}$ & Total \\
\hline $\begin{array}{l}\text { Single-location establishment } \\
\text { Branch establishment } \\
\text { Total }\end{array}$ & $\begin{array}{r}117 \\
8 \\
125\end{array}$ & $\begin{array}{l}62 \\
20 \\
82\end{array}$ & $\begin{array}{r}179 \\
28 \\
207^{\mathrm{a}}\end{array}$ \\
\hline
\end{tabular}

Two establishments did not answer this question. 
TABLE 4 Number of Respondents to Producer

Service Establishment Survey, by

Establishment Type

\begin{tabular}{lr}
\hline \multicolumn{1}{c}{ Establishment Type } & Number \\
\hline Single-location establishment & 128 \\
Branch establishment of multilocation firm & 48 \\
Headquarters establishment of multilocation firm & 31 \\
Regional or local sales office & 4 \\
Data entry or data processing office & 1 \\
Service establishment of manufacturing firm & 1 \\
Total & $213^{\mathrm{a}}$ \\
\hline
\end{tabular}

a One establishment did not answer this question.

Table 5 classifies the producer service respondents according to the primary service they provided. According to this classification, the largest number of establishments provided consulting services of some scrt. Of the 213 establishments that responded to this question, $87(40.8 \%)$ said consulting was their primary activity. The consulting services were in areas such as engineering, construction, economics, and management. Computer and telecommunications had the second largest number of establishments: 30 (14\%). Employment services and advertising and market research followed, with 27 (12.7\%) establishments each. The other services (banking services, accounting and bookkeeping, data processing, general services, payroll and benefits, legal services, real estate, and insurance) were provided by only one or a few establishments. This distribution resulted from the screening, which had eliminated most of the consumer services. Undoubtedly, many of the establishments in these under-represented categories, such as banks and insurance companies, direct most of their business to consumers instead of other firms. 
TABLE 5 Number of Respondents to Producer Service Establishment Survey, by Primary Service Provided

\begin{tabular}{lc}
\multicolumn{1}{c}{ Type of Service } & Number \\
\hline Consulting services & 87 \\
Computer and telecommunications & 30 \\
Employment services & 27 \\
Advertising and market research & 27 \\
Banking services & 8 \\
Accounting and bookkeeping & 5 \\
Data processing & 5 \\
General services & 5 \\
Payroll and benefits & 1 \\
Legal services & 1 \\
Real estate & 1 \\
Insurance & 1 \\
Other or not classified & 15 \\
Total & $213^{\mathrm{a}}$ \\
\hline
\end{tabular}

ane establishment did not answer this question. 


\section{IMPORTANCE OF AMENITIES AS A BUSINESS LOCATION FACTOR}

This section summarizes the rankings of business location factors as given by different types and sizes of manufacturing and producer service establishments that responded to the questionnaires. Also discussed are the results of the on-site interviews with selected plant managers and owners. Although the emphasis in this discussion is on factors considered to be amenities, other factors of significance are also discussed. The results from the manufacturing establishment survey are discussed first; results from the producer service establishment survey follow. Two levels of search are considered: local and regional.

\subsection{MANUFACTURING ESTABLISHMENTS}

\subsubsection{Local Search}

Table 6 summarizes the rankings of the local factors for all manufacturing establishments participating in the study. This table, and others following, rank factors according to a rating system that assigns a value of 4 to an extremely important response, 3 to a very important response, 2 to an important response, 1 to a moderately important response, and 0 to an unimportant response. The weights are multiplied by the number of responses for each category, added across the entire location factor, and divided by the total count to arrive at an average weight or rating.

The questions concern the importance of the various factors that would affect the choice of a locality if the establishment locator were to select a new location for the establishment now. The questions ask, "How would you rate the importance of (location factor) in evaluating a local site?" As indicated in Table 6, low business taxes, with an average rating of 3.32 , was rated by manufacturers as the most important factor in a local search. More than 53\% of the respondents said that this factor was extremely important in the choice of a location. Only two of the 209 respondents said that low business taxes would be unimportant in the selection of a new location for their establishment. Second to low business taxes is an available building or building site, which scored 3.14. Ninety respondents $(43 \%)$ noted this as extremely important, and only four (1.9\%) viewed it as unimportant. In two of the on-site interviews, the availability of a building for the business was the only significant factor in the selection of a location. Government attitude toward business was rated third, with an average rating of 3.07. The first amenity factor, quality of education, was rated fourth, with an average rating of 2.97. Following quality of education were low personal taxes and production workers, with average ratings of 2.87 and 2.78, respectively. Quality of the physical environment was rated seventh, with an average rating of 2.69. Slightly more than $30 \%$ of the manufacturing establishment respondents viewed the physical environment as extremely important; 10 respondents $(4.8 \%)$ said it was unimportant. Completing the top 10 local factors were government incentives, nonunion labor, and quality of housing. 


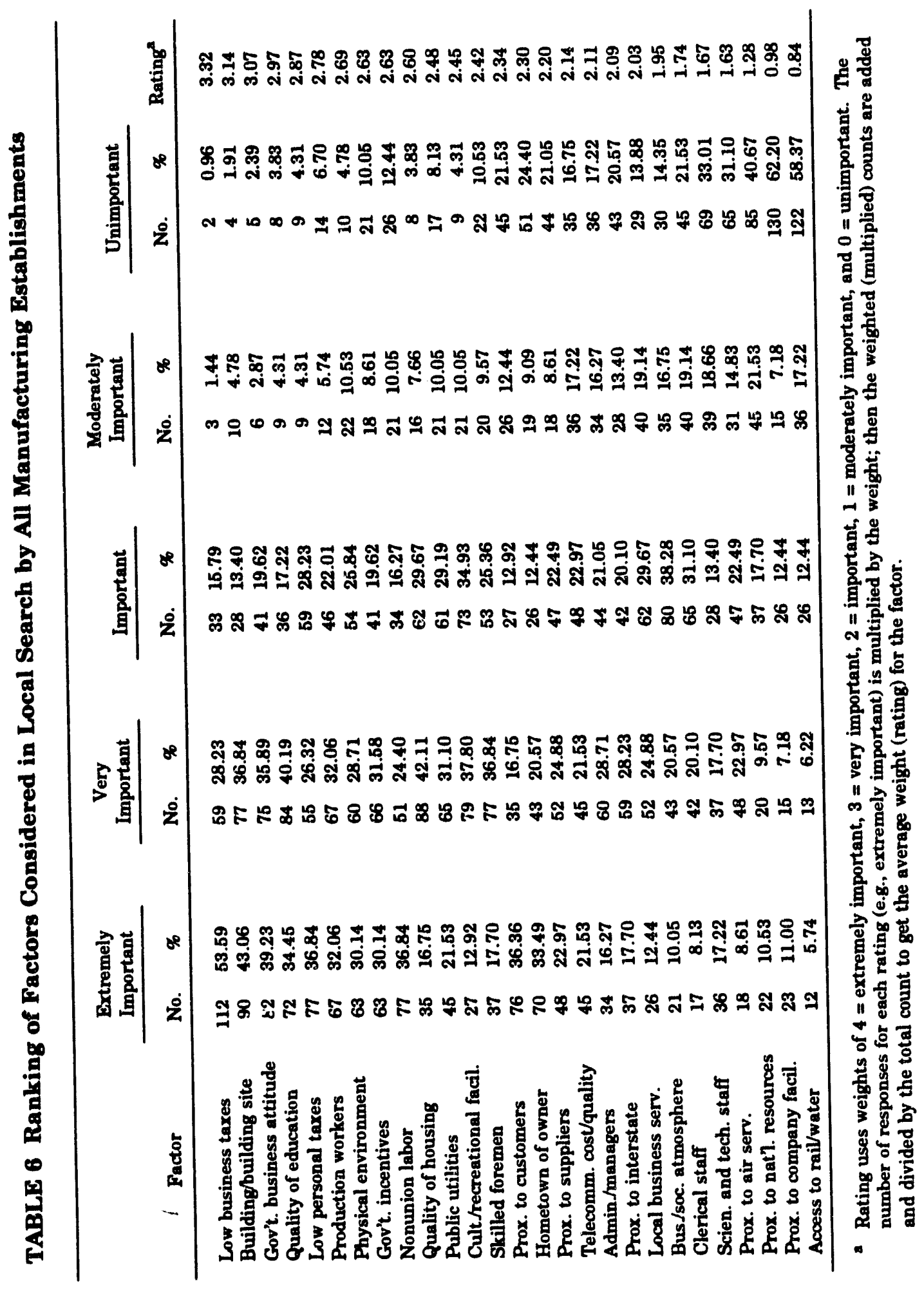


There are some surprising results in Table 6. In surveys such as this, low business taxes are often rated high, but they are not necessarily the highest-rated factor, as occurred here. Also, the hometown of the owner, which is usually an important consideration, particularly for single-location establishments, was not rated very high. The relatively low rating of proximity to interstate highways (rated nineteenth) is quite surprising wher the rating is compared with the findings of other studies (Kale and Lorisdale 1979). More than $20 \%$ of the respondents said that proximity to interstates would be unimportant as a local factor if they were to select a new site for their plant. Part of the explanation for this is because the surface highway systems in Denver and Salt Lake City are relatively good. All of the manufacturering establishments visited had access to main roads and ample space for trucks to turn and make deliveries. In other areas of the country, urban congestion or narrow, winding roads may require plants that require deliveries and pickups by truck to be located as close as possible to interstate highways.

\subsubsection{Distinctions between Single-Iocation Establishments and Branch Establishments of Multilocation Firms}

The rankings of factors considered in a local search are shown in Table 7 for singlelocation establishments and in Table 8 for branch establishments. Low business taxes, building and building site, and government attitude toward business were the top three factors for both types of establishments. Low business taxes was still rated first by both single-location establishments and branch establishments. However, about 57\% of the singlelocation establishment respondents rated low business taxes as extremely important, whereas $46 \%$ of the branch establishments rated this factor as extremely important. Single-location establishments rated the availability of a building or building site as second, whereas this factor was rated third by branch establishments. Again, many single-location establishments simply moved into an available building to start, so the existence of a building was the dominant factor. However, more than 53\% of the branch establishment respondents said that the availability of a building or building site was extremely important in their choice of a location. Government attitude toward business was rated second for the branch establishments, with $36 \%$ of the respondents saying it was extremely important and $50 \%$ listing it as very important. Government incentives was rated fourth for branch establishments and eleventh for single-location establishments. This difference is not surprising, since firms opening branch establishments are likely to look for various incentives offered by state and local governments.

The quality of education rated fourth for single-location establishments and fifth for branch establishments. More than 38\% of the single-location establishments said that education was extremely important to them, but only $25 \%$ of the branch establishments listed education as extremely important. Part of the explanation for this result is that the owner of a single-location establishment usually lives in the community in which the establishment is located, so education is viewed as both a business factor and a personal factor for selecting the community. In the case of branch establishments, the purely personal factors are of 


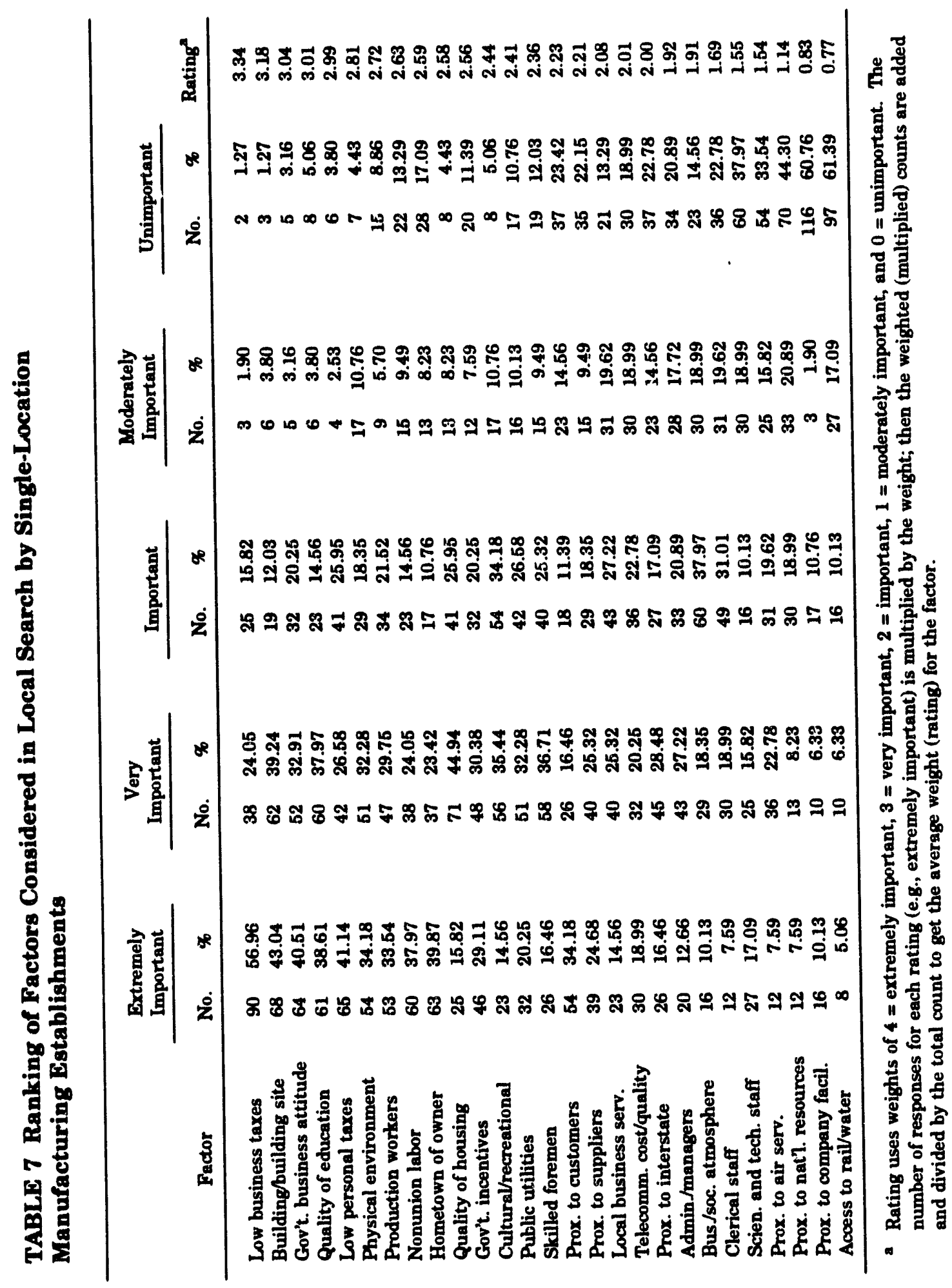




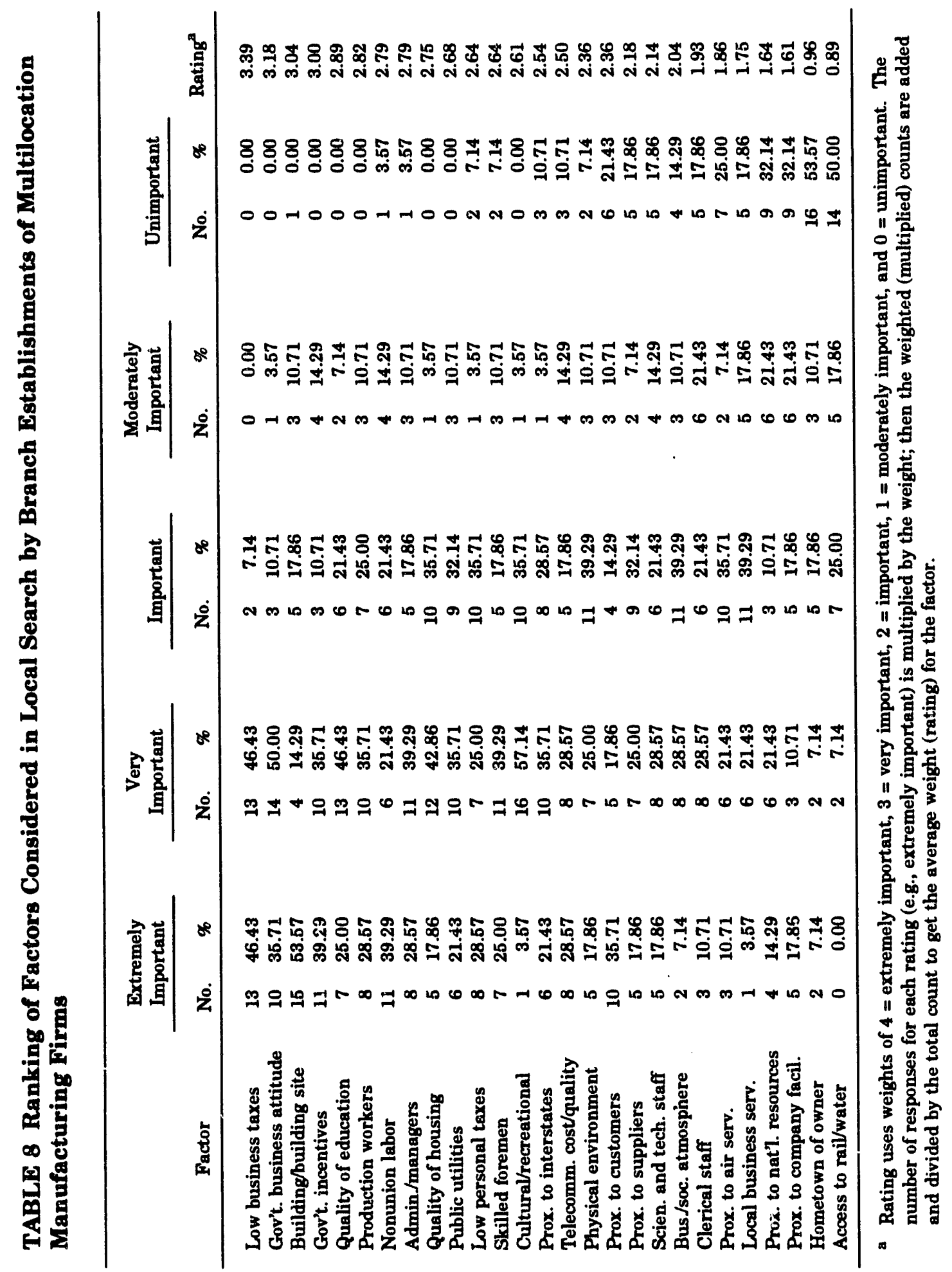


less value in the selection of a locality, since those in management making the location decision do not necessaril" move to the new location. The factor "hometown of owner" was rated as extremely important by only two of the branch establishments but by almost $40 \%$ of the single-location establishments. This distinction between purely personal factors and business factors was noted jy Greenhut (1956).

The distinction between purely personal factors and business factors may also be responsible for single-location establishments ranking low personal taxes (rated fifth) and quality of the physical envircnment (rated sixth) higher than did the branch establishments. Low personal taxes was rated eleventh for the branch establishments. Quality of the physical environment was ranked sixteenth. Quality of housing was rated tenth for the single-location establishments and ninth for the branch establishments. Cultural and recreational factors were rated twelfth for the sirıle-location establishments and thirteenth for the branch establishments.

The cimparison between single-location and branch establishments does not offer many surprises with regard to the importance of amenities in business location decisions. Amenity factors were not lated as the top factors by either category of establishments, but quality of the physical environment did rate high for the single-location establishments. In the interviews with the owners, those who owned small establishments did not distinguish hetween amenity factors of interest to them personally and those of importance to the business. A typical response was "I decided to stay here because I like $x x x$." There was no significant difference in the rankings of the other amenity factors between single-location and branch establishments.

\subsubsection{Distinctions between Larger and Smaller Establishments}

Table 9 lists the rankings of factors considered in a local search by establishments with fewer than 20 employees; Table 10 provides the rankings for establishments with 20 or more employees. Again, low business taxes was rated first by both categories of establishments. However, slmost $60 \%$ of the smaller establishments said that low business taxes were extremely important in the choice of a locality, compared with about $45 \%$ of the larger establishments. An available building or building site was rated second by smaller establishments and third by larger establishments, and government attitude toward business was rated second by larger establishments but fourth by smaller establishments. Quality of education was also rated high by both categories of establishments: fourth by larger establishments and fifth iy smaller establishments. Beyond these commonly highly regarded factors, there were important differences in the rankings of the local factors between smaller and larger establishments.

Cost-related factors were ranked higher by larger establishments, while many personal factors were ranked higher by sualler establishments. As noted previously, it is not surprising that low personal taxes was rated third by smaller establishments but eleventh 


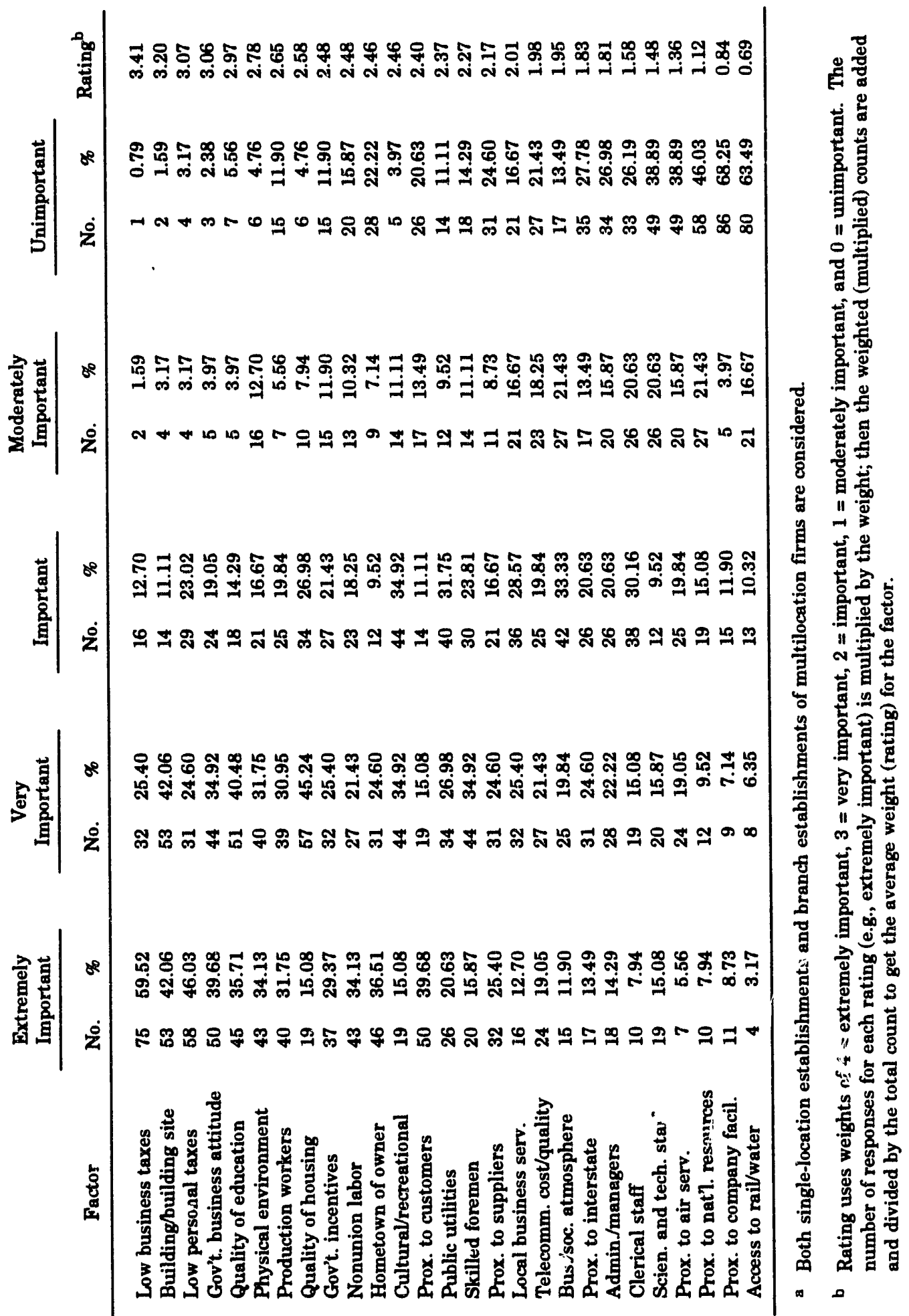




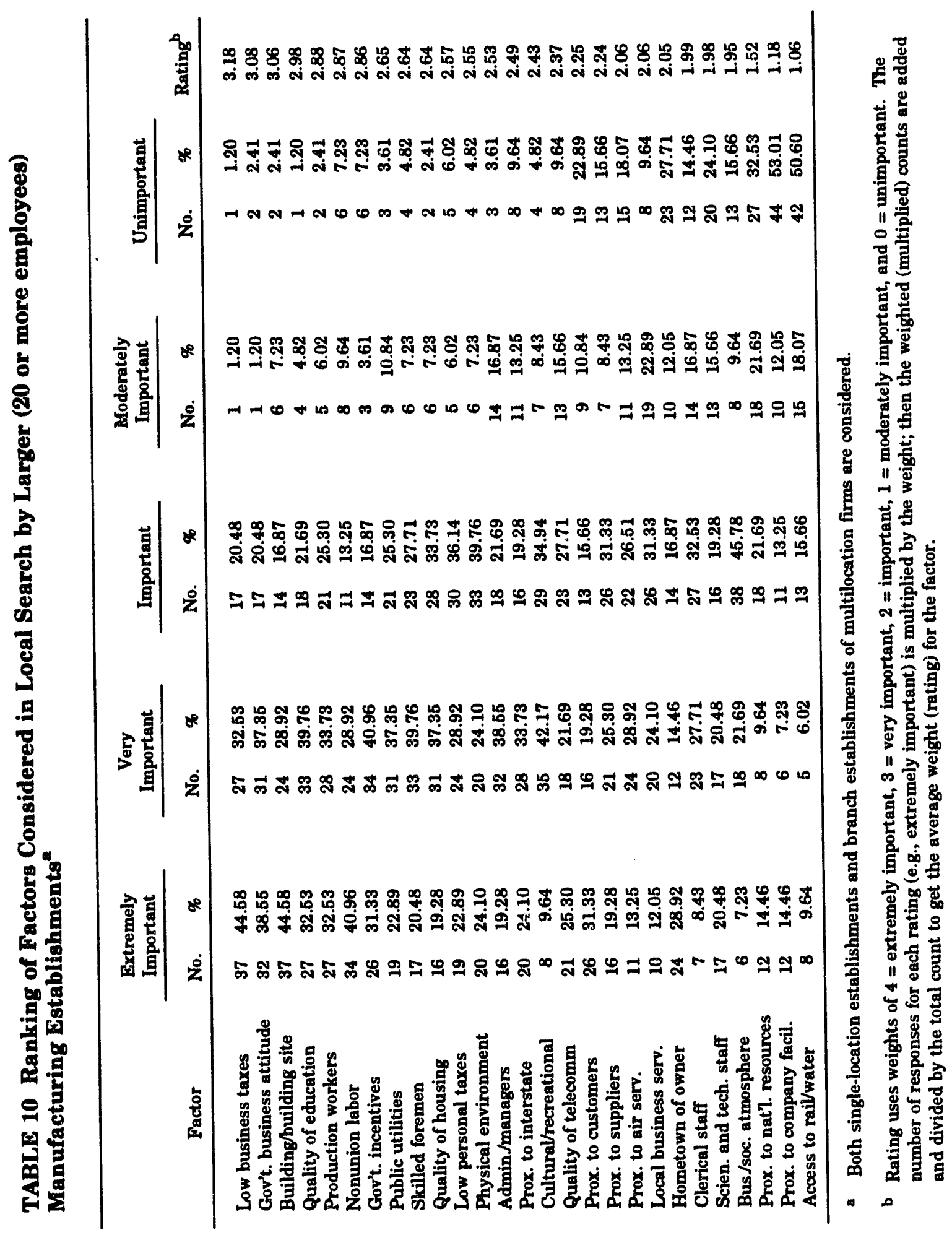


by larger establishments. The quality of the physical environment was rated sixth by the smaller establishments but twelfth by the larger establishments. The cost-related factors of availability of production workers, nonunion labor, government incentives, public utilities, and skilled foremen all rated higher for larger establishments than for smaller establishments. Availability of production workers ranked fifth for larger establishments and seventh for smaller; government incentives ranked seventh for larger establishments and ninth for smaller; nonunion labor ranked sixth for larger establishments and tenth for smaller; and public utilities ranked eighth for larger establishments and fourteenth for smaller.

In their rankings of amenity factors, larger and smaller establishments differed in much the same way that single-location and branch establishments differed. Quality of the physical environment ranked sixth for smaller establishments and twelfth for larger establishments. Cultural and recreational amenities ranked twelfth for smaller establishments and fifteenth for larger ones.

Table 11 lists the rankings of local factors for single-location establishments with fewer than 20 employees; Table 12 lists the rankings of local factors for branch establishments with 20 or more employees. One would expect the smaller single-location establishment to represent an entrepreneurial establishment in which an individual started a business, often in his or her own community. A larger branch establishment would be likely to have been located after an intensive business location search process. Evidence for this hypothesis is that hometown of owner was ranked ninth by smaller single-location establishments and last by larger branch establishments.

Again, low business taxes was the factor ranked highest by both categories. More than $60 \%$ of the smaller, single-location establishments rated business taxes as extremely important, compared with $40 \%$ of the larger branch establishments. The only other factors rated high by both of these entities were government attitude toward business (which ranked fourth for smaller single-location establishments and second for larger branch establishments) and quality of education (which ranked fifth for smaller single-location establishments and fourth for larger branch establishments). Amenity factors other than quality of education were ranked higher by smaller single-location establishments, whereas traditional economic factors were most important to larger branch establishments. The physical environment was ranked sixth by smaller single-location establishments and seventeenth by larger branch establishments. Cultural and recreational amenities were rated tenth by smaller singlelocation establishments and thirteenth by larger branch establishments.

\subsubsection{On-Site Interviews}

To obtain more information concerning the importance of amenities as a business location factor, interviews were conducted with owners or managers of selected establishments in Salt Lake City and the Denver/Boulder areas that had rated amenity factors as being very important in their location decisions. Salt Lake City is home to the 


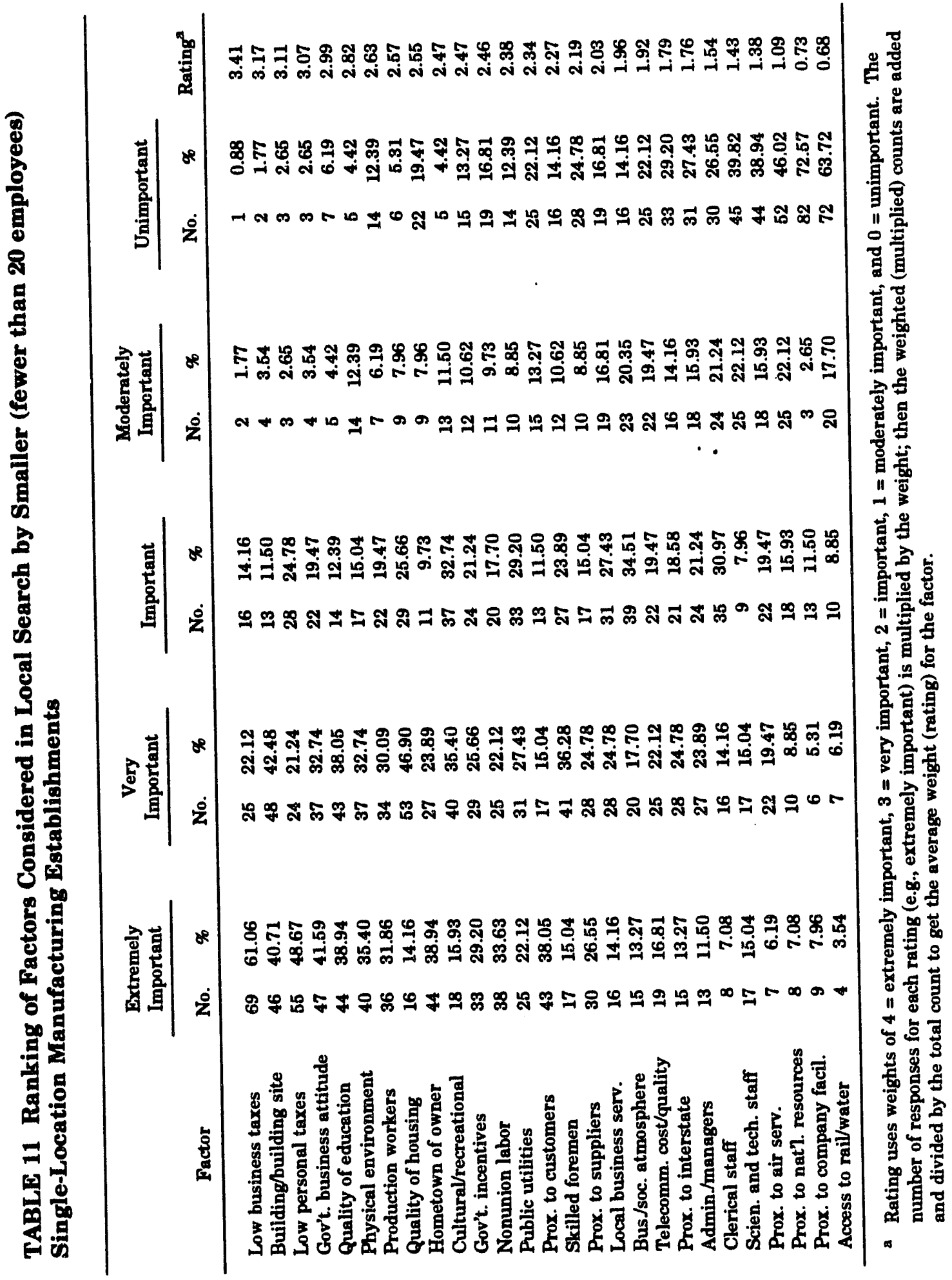




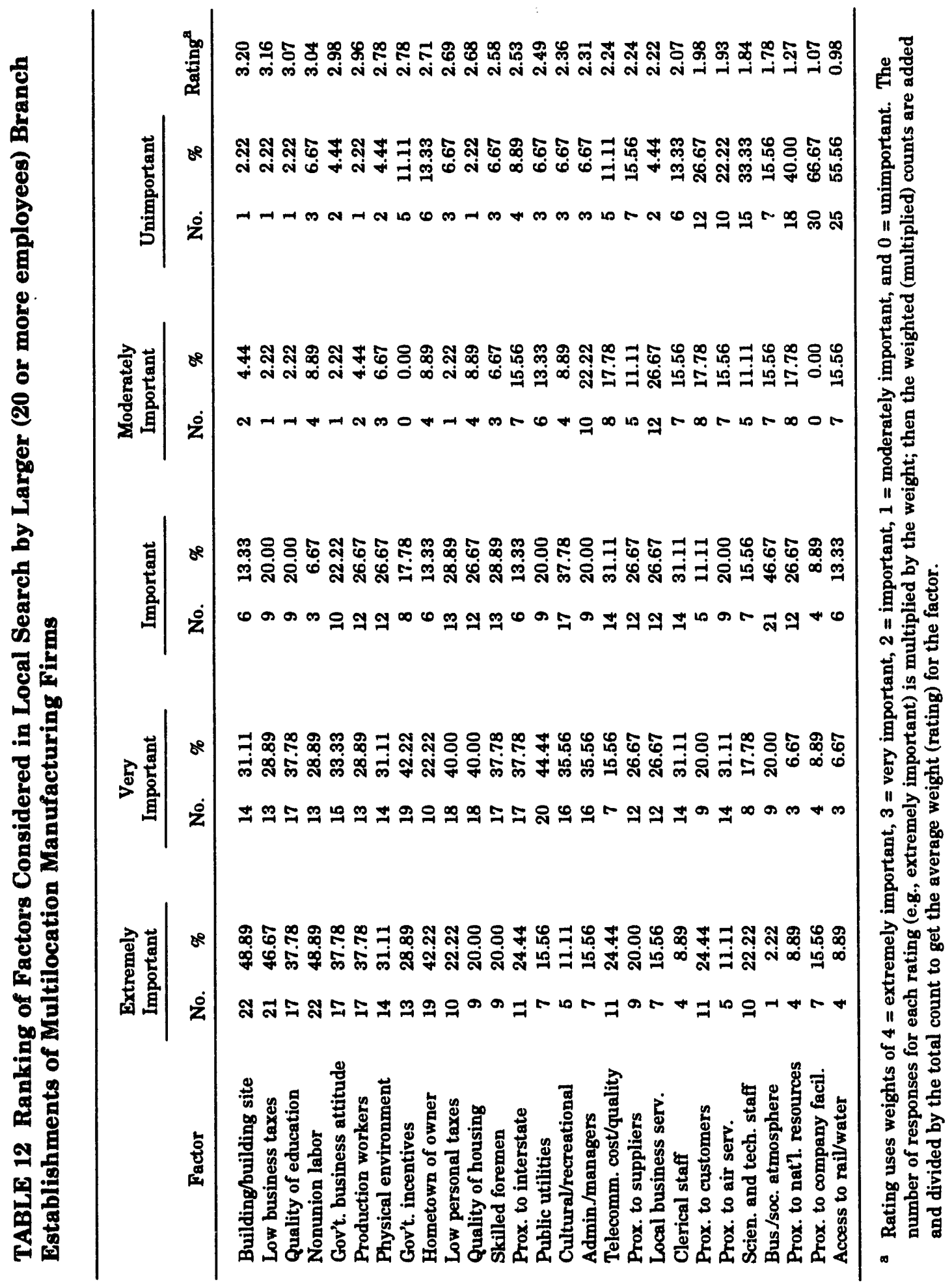


Church of Jesus Christ of the Latter Day Saints, which has a great presence in the area. The family values emphasized by the church are noticeable even during a short visit to the area. The Salt Lake City area is also rich in physical amenities. The foothills of the Wasatch Range provide a spectacular backdrop for the city. Some of the finest downhill skiing in the country is available there. There are park facilities, hiking trails, and resorts on the mountains. Abundant outdoor recreational opportunities are also available in the Denver and Boulder areas and the adjacent Front Range of the Rocky Mountains.

The interviewers reviewed the questionnaire, discussed the history of the company, considered the use of business services and labor, and discussed the importance of amenities and disamenities in staying in the existing location or locating elsewhere. Interviewers in the Denver/Boulder area also discussed the local nuclear facilities. All those interviewed in the Salt Lake City and Denver/Boulder areas emphasized the importance of the physical environment to themselves and their employees. Most said that they and their employees hiked, skied, hunted, or fished almost every weekend in the nearby mountains. Some establishments in the Salt Lake City area organized hunting weekends or mountain outings. It was obvious that proximity to the nearby mountains was an important reason for staying in the area. One software manufacturer in Boulder actually selected the site on the basis of its amenity factors. It considered Boulder to be attractive because it is a small town without big-city problems and has everything the company needs. The establishment is in western Boulder next to the mountains and adjacent to a park in a very attractive setting. This location was chosen even though the company paid a premium for the building because the atmosphere is peaceful and conducive to the writing of software.

Not all establishment owners and managers said that amenities were important in the selection of their business location. Amenities were not the primary factor for locating a silk screen manufacturing plant in Aurora, Colorado, according to one of the firm's owners. The site was chosen simply because it was the home of the founders of the company. The owner was not worried about the plant's proximity to the Rocky Mountain Arsenal, which is a nuclear waste site. He maintained that the Stapleton Airport would create more of a hazardous waste disposal problem than the nuclear waste site because of the jet fuel and diesel fuel that has seeped into the ground.

An important point missed in the questionnaire for the Salt Lake City sample was the importance of the Mormon Church. Several owners or managers mentioned that the reason that they came to the area or would remain in the area was to be near the home of the Mormon Church. Several said that they have received résumés from qualified technical people from other areas who were seeking employment in the Salt Lake City area mainly to get close to the Church. The Church, because of its emphasis on family values, could help improve the liveability of communities, because many of the community leaders share these values and work to maintain a community with good schools, parks, and a clean appearance.

The high-quality education system was also mentioned as an advantage for staying in both the Salt Lake City and Denver/Boulder areas. Several of those interviewed mentioned that they have no problem finding technical people from the local universities. 
In both locations, it was said that people came from other states (many from the eastern states) to attend local universities (University of Colorado and University of Utah) and decided to stay because of the lifestyles in these areas. Most managers said that it was not difficult to find qualified employees and that many applications are received from individuals seeking to move into the areas from other states.

In many of the tables shown in this section, the importance of hometown as a location factor is noted. However, this factor is also related to the amenity factors, which was brought out in the interviews. Many of the individuals questioned said that they were raised in either the Denver/Boulder or Salt Lake City areas, moved away, but later decided to come back to settle. In some cases, this meant that they started a new business. The attractiveness of the areas and the rich amenities were cited as reasons for wanting to come back. Also, problems in other areas, particularly in the Northeast and California, drove many back to the western mountains.

Two disamenities were mentioned by several of those interviewed, although some questioned about disamenities responded that "nothing comes to mind." One problem was the increasing traffic congestion that is resulting from the growth of the Denver/Boulder and Salt Lake City areas. This problem was expressed as being more serious in the Denver/Boulder area than the Salt Lake City area, even though many in the Salt Lake City area expressed concern that the city has been growing too quickly. Several people in both areas mentioned the "brown cloud" over the cities. In Salt Lake City, the situation is worse on the western, lower side of the valley than on the eastern side of the valley or the slopes of the mountains. Another problem mentioned was the emergence of street gangs in western Salt Lake City; however, some of those questioned did not believe that the gangs were a serious problem. No one questioned said that he or she would move because of these factors. When managers in the Denver/Boulder area were asked about the nuclear facilities, they acknowledged their existence but denied that these facilities or related problems were serious or that they would affect their business location decision. Several said that the problem has been resolved and so it is no longer an issue. One person, a former real estate agent who now manages a business, said that the Rocky Flats Plant "cast an edge" on the city. He also said that people looking for homes wanted to know about the facility.

\subsubsection{Regional Search}

The questionnaire asked about factors important in selecting a region, if indeed the individual would undertake a regional search to select a new location for a manufacturing business. It was found that most business people would not undertake a regional-type search to find a site to open a manufacturing establishment. The results of this survey are no different from those of other surveys that have investigated the regional search. About 36\% of the respondents said that they would evaluate different regions of the country if they were to make a decision now to open a new establishment.

Table 13 summarizes the rankings of the regional factors for all respondents. The factor ranked highest, with an average rating of 3.29 , was low business taxes. However, 


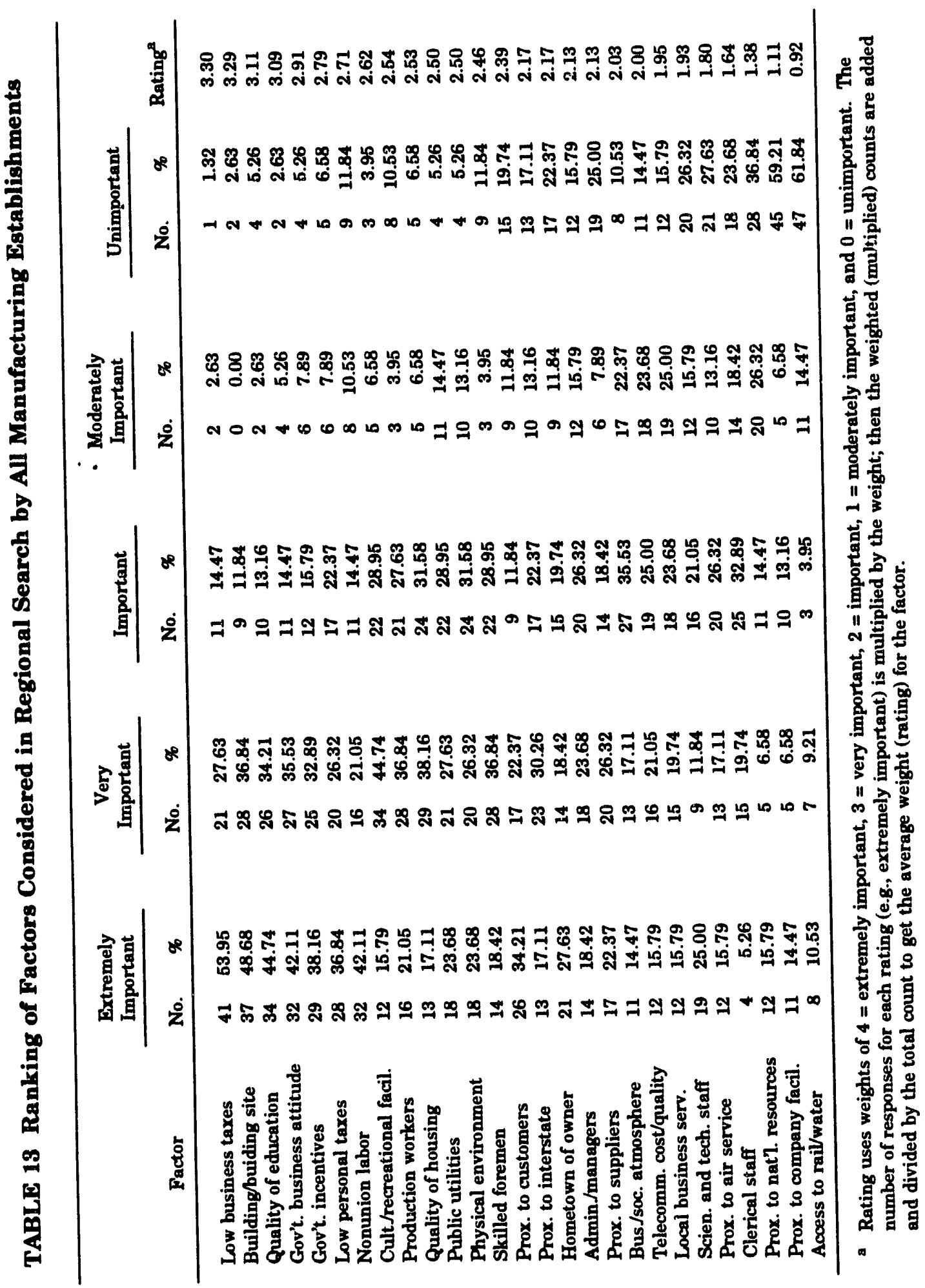


closely following, with an average rating of 3.29 , was the cost and availability of a suitable building or building site. This high rating is troubling since this factor is generally not considered a regional factor. However, because many people in the West are aware of the high land and building costs in California, the cost of a building site could be considered a regional factor. Quality of education was rated third, community and state attitude toward business was fourth, and government incentives to attract industry was fifth. In the localsearch section for all respondents, low business taxes was also the factor ranked highest, and building/building site, government attitude toward business, and quality of education were also listed in the top five. Amenity factors did not usually score as high in regional searches as they did in local searches. Most higher-scoring factors were directly related to the cost of opening and operating a business.

\subsubsection{Summary}

Other than the quality of education, which is both an amenity and a business location factor (the quality of education is related to the quality of the work force), amenity factors were not given a high rank in local searches by most categories of manufacturing establishments included in this study. Although the quality of the physical environment ranked relatively high (particularly for smaller single-location establishments), in general, economic factors affecting the business and the owner's or manager's private financial situation (e.g., high personal taxes) were ranked highest by manufacturing establishments. However, in personal interviews, the importance of amenities was mentioned repeatedly by owners and managers as a reason for deciding either to go into business in a community or to not move away. Amenity factors, particularly access to outdoor recreation areas and the environmental quality of the communities, were rated as important for the owners and managers and for the workers. There was little evidence of concern about the risk of nuclear or other noxious facilities in the Salt Lake City or Denver/Boulder areas.

\subsection{PRODUCER SERVICE ESTABLISHMENTS}

\subsubsection{Local Search}

Table 14 summarizes the rankings of factors considered in a local search by the producer service establishments responding to the survey. These rankings were determined by the same weighting system described for the manufacturing establishments, and the rankings were based on the average ranking of each local factor. Amenity-related factors were much more important to producer service establishments than they were to manufacturing establishments, according to the results of this survey. As indicated in Table 14, quality of life was ranked as the top local factor by producer service establishments, with more than $53 \%$ of the respondents saying it would be very important in their selection of a locality. Only two of the 214 respondents said that quality of life would be unimportant 


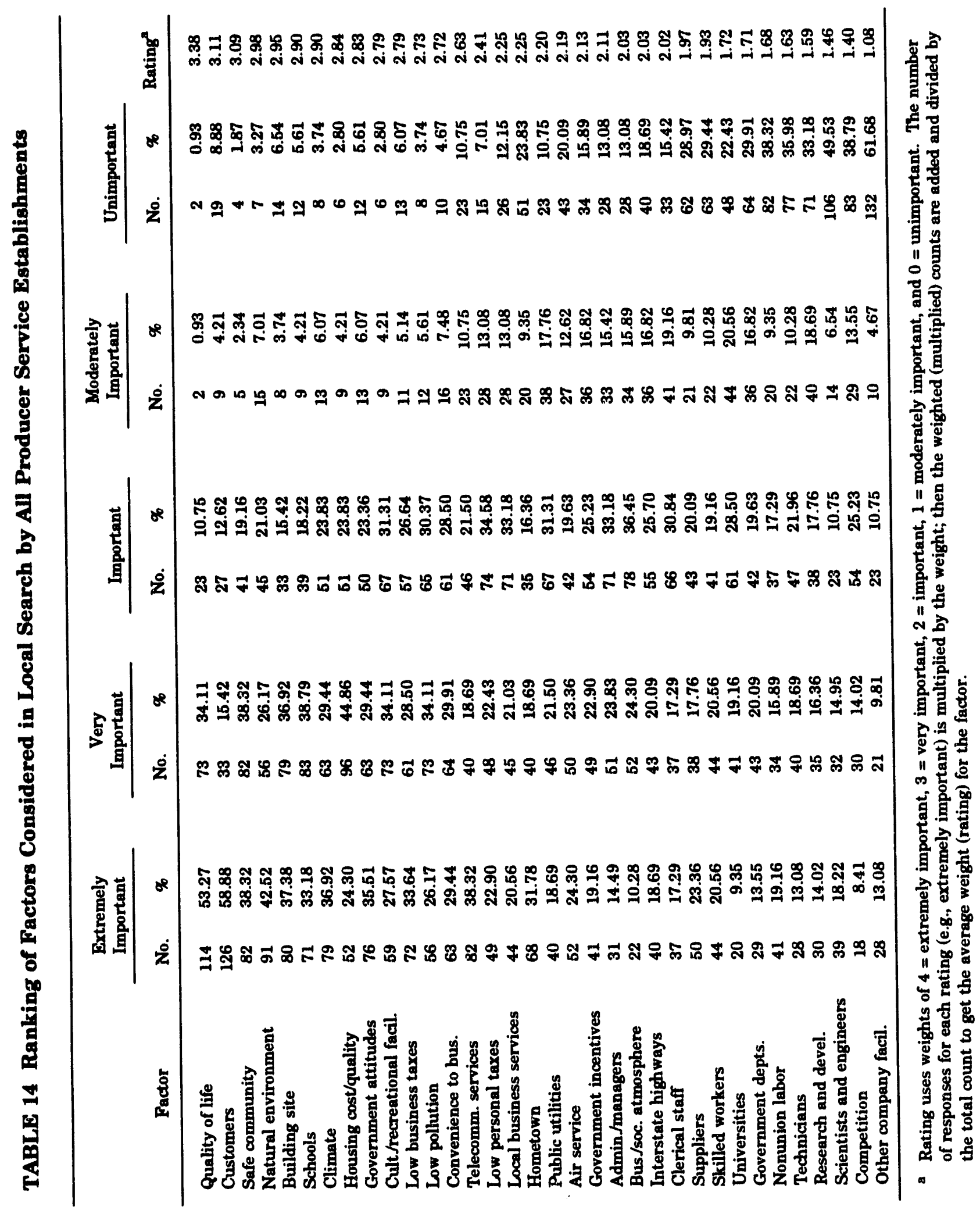


in their choice of a locality. Two other amenity factors were listed among the top five factors for the producer service establishments. A safe community was ranked third (behind access to customers), and the quality of the natural environment ${ }^{1}$ was ranked fourth. Four other amenity-related factors were ranked among the top 10 local factors: schools (ranked sixth), climate (seventh), housing (eighth), and cultural and recreational facilities (tenth). Factors that were ranked high by manufacturing establishments were not as highly regarded by producer service establishments. For instance, low business taxes was by far the most important local factor to the manufacturing establishment respondents, but business taxes was rated eleventh by producer service establishments. Low personal taxes was also not a very important factor to producer service establishments, nor was access to workers, scientists, or engineers.

\subsubsection{Distinctions between Larger and Smaller Establishments}

Table 15 lists the rankings of factors considered in a local search by producer service establishments with fewer than 20 employees; Table 16 provides the rankings for producer service establishments with 20 or more employees. Quality of life was the factor ranked highest by both smaller and larger establishments, but the factor was much more important to smaller establishments. More than $60 \%$ of the 143 producer service establishments with fewer than 20 employees said that quality of life was extremely important, compared with $39.4 \%$ of the larger establishments. This factor ranked high because few respondents listed it as unimportant or moderately important. The quality of the natural environment was ranked second by smaller establishments but eleventh by larger establishments. More than $50 \%$ of the smaller establishments said that the quality of the natural environment was extremely important, compared with $26.7 \%$ of the larger establishments. The interviews indicated that many owners, managers, and employees of smaller establishments were outdoor enthusiasts. A safe community ranked high for both smaller and larger establishments - third for smaller establishments and fourth for larger establishments. Climate, schools, cultural/recreational facilities, and housing scored higher for smaller establishments than larger establishments. Low pollution was ranked eleventh by smaller establishments and thirteenth by larger establishments. It is noteworthy that businessrelated factors scored relatively low for larger establishments - much lower than many of the "softer" amenity factors. The factor of convenience (a location convenient to other establishments in the same business, air service, interstate highways, workers of different types with different skills, or public utilities) was ranked surprisingly low by larger producer service establishments. Telecommunication services was ranked higher by larger establishments and lower by smaller establishments. It is also surprising that access to universities was ranked low by producer service establishments.

1 The term physical environment was used in the manufacturing establishment survey; natural environment was used in the producer service establishment survey. 


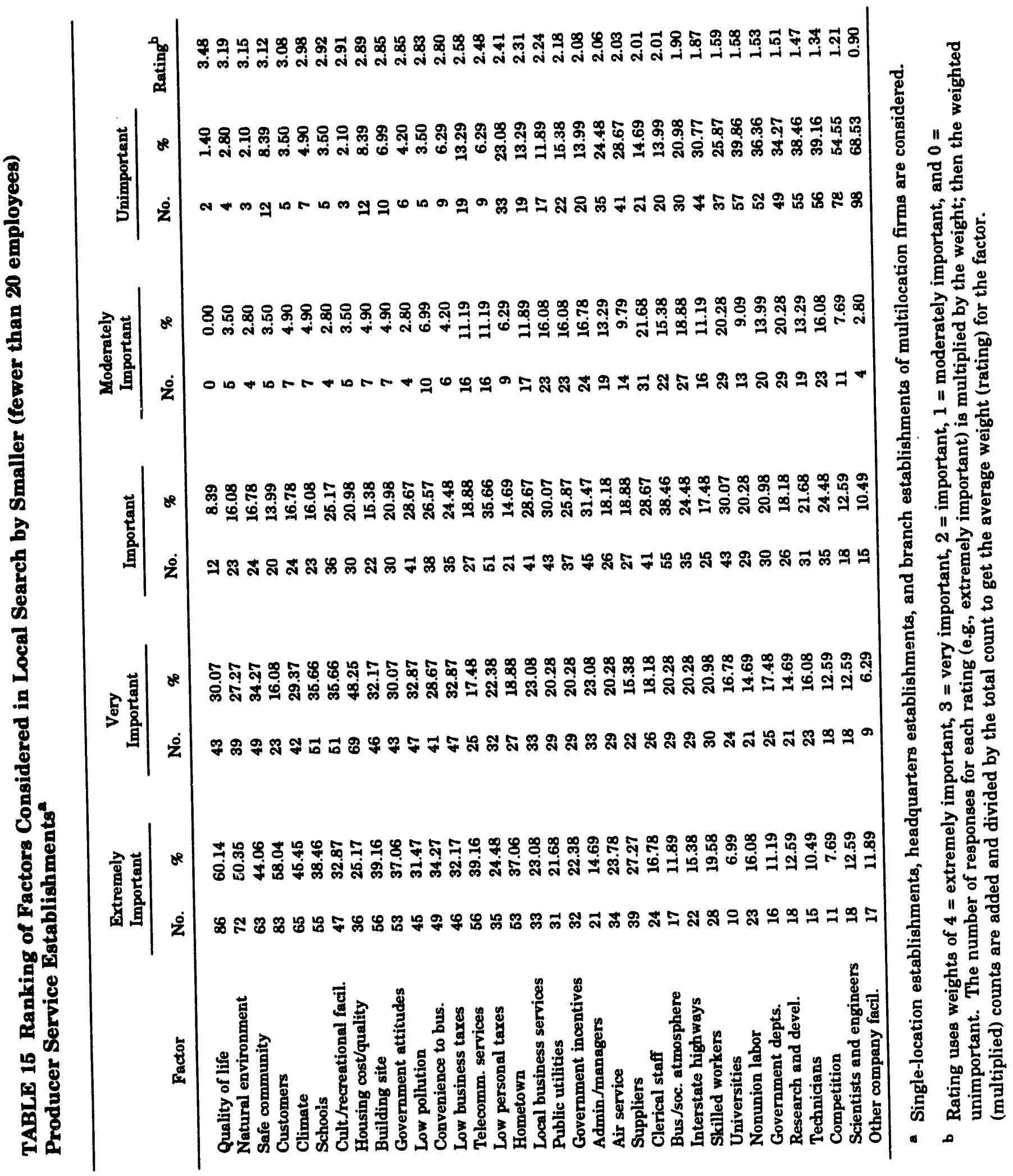




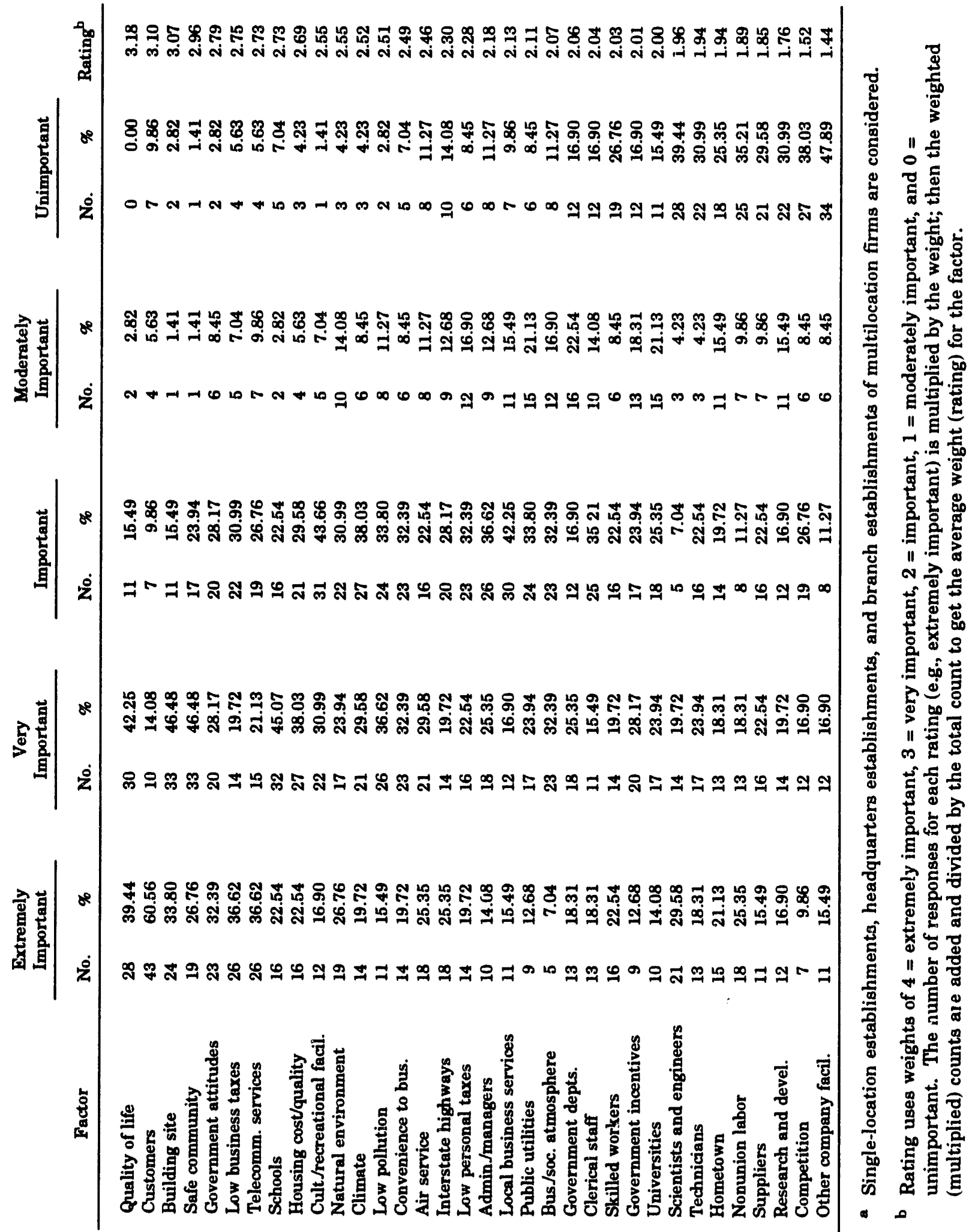




\subsubsection{Differences by Establishment Type}

The questionnaire asks whether the service establishment is best described as a headquarters establishment of a multilocation firm, a single-location establishment, a branch establishment of a multilocation firm, or several other possibilities. Of the 214 respondents to the producer service establishment survey, 31 were headquarters of multilocation firms, 128 were single-location establishments, and 48 were branch establishments of multilocation service firms.

Table 17 gives the ranking of local factors of importance to the 31 headquarters establishments. The top factor was quality of life, and two other amenity factors - a safe community and the natural environment - were listed among the top five local factors. Access to customers and low business taxes were listed second and third. Headquarters plants are usually occupied by management, scientific, and technical personnel. The importance of quality of life as the dominant iocal factor uncerscores the fact that a desirable location offers advantages in attracting such establishments.

Table 18 ranks local factors for the 128 single-location producer service establishments. Single-location establishments were very concerned about amenity factors. Quaiity of life was most important to them, followed by safe community, natural environment, climate, and schools. The first economic factor, access to customers, was rated sixth. Sixty-six percent of the single-location establishment respondents said that quality of life was extremely important, and only one respondent said that quality of life was either moderately important or unimportant. Following access to customers were additional amenity factors. Cultural and recreational facilities was rated seventh, housing cost and quality eighth, and low pollution tenth. Amenity factors are definitely a high priority to small business people when they search for a location.

Table 19 ranks local factors for the 48 branch establishments of multilocation producer service firms. Amenity factors were less important to branch establishments than single-location establishments. Access to customers and building site were the top two factors to branch establishments; more than $\mathbf{7 7 \%}$ of the respondents said that access to customers would be an extremely important factor in a local search for a new business location. Quality of life was the third-highest-rated factor, but only $31 \%$ of the respondents said that it was extremely important. Other amenity factors, such as climate, natural environment, and low pollution, did not rank high for the branch establishments. For the larger (t) ise with 20 or more employees) branch establishments of multilocation producer service firms, access to customers ranked high. As shown in Table 20, more than $80 \%$ of the respondents said that access to customers was extremely important. Schools ranked second for this group of establishments, followed by building site and government attitude toward business.

\subsubsection{On-Site Interviews}

Interviews were conducted with managers and owners of producer service establishments in the Salt Lake City and Denver/Boulder areas. Like the interviews with 


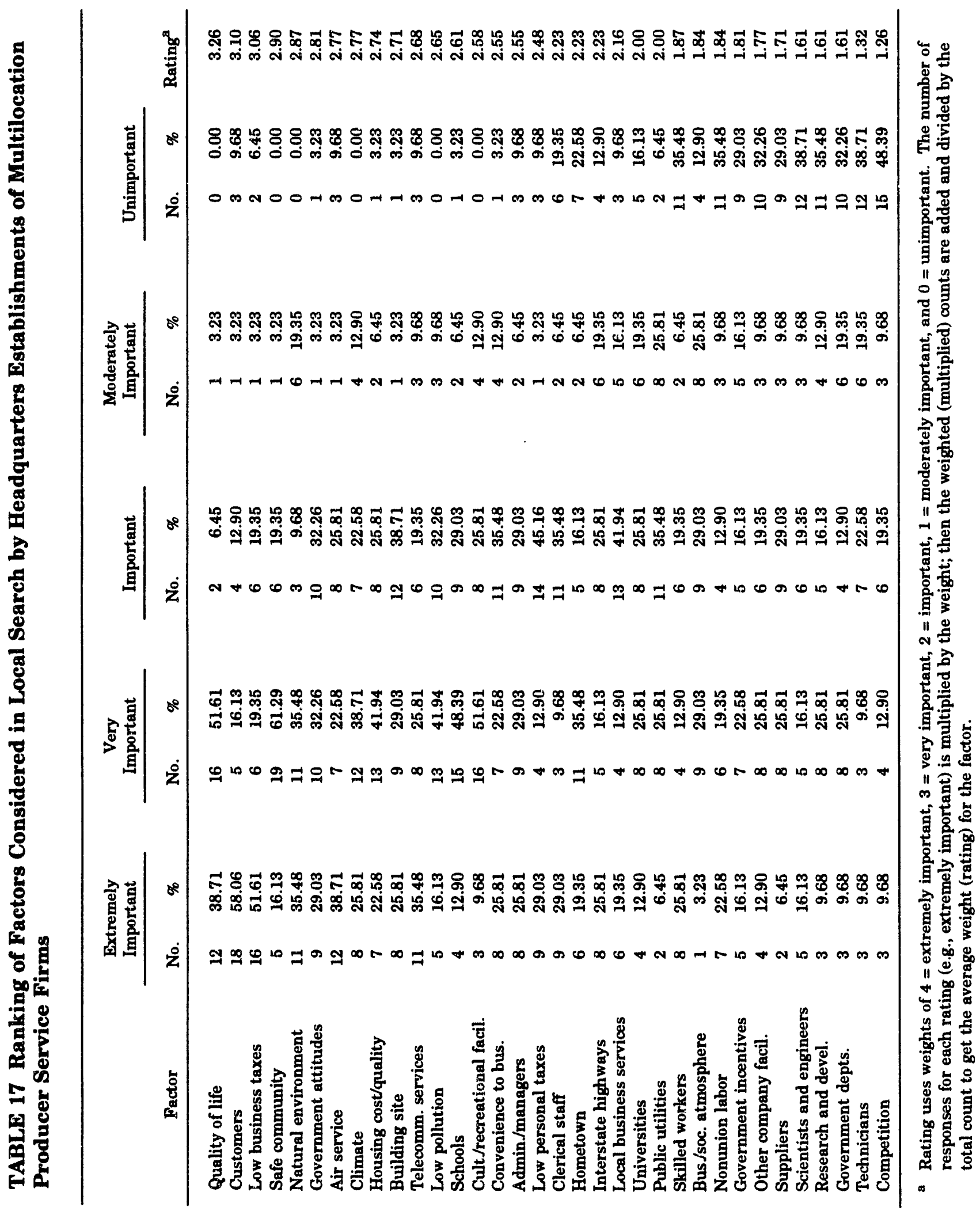




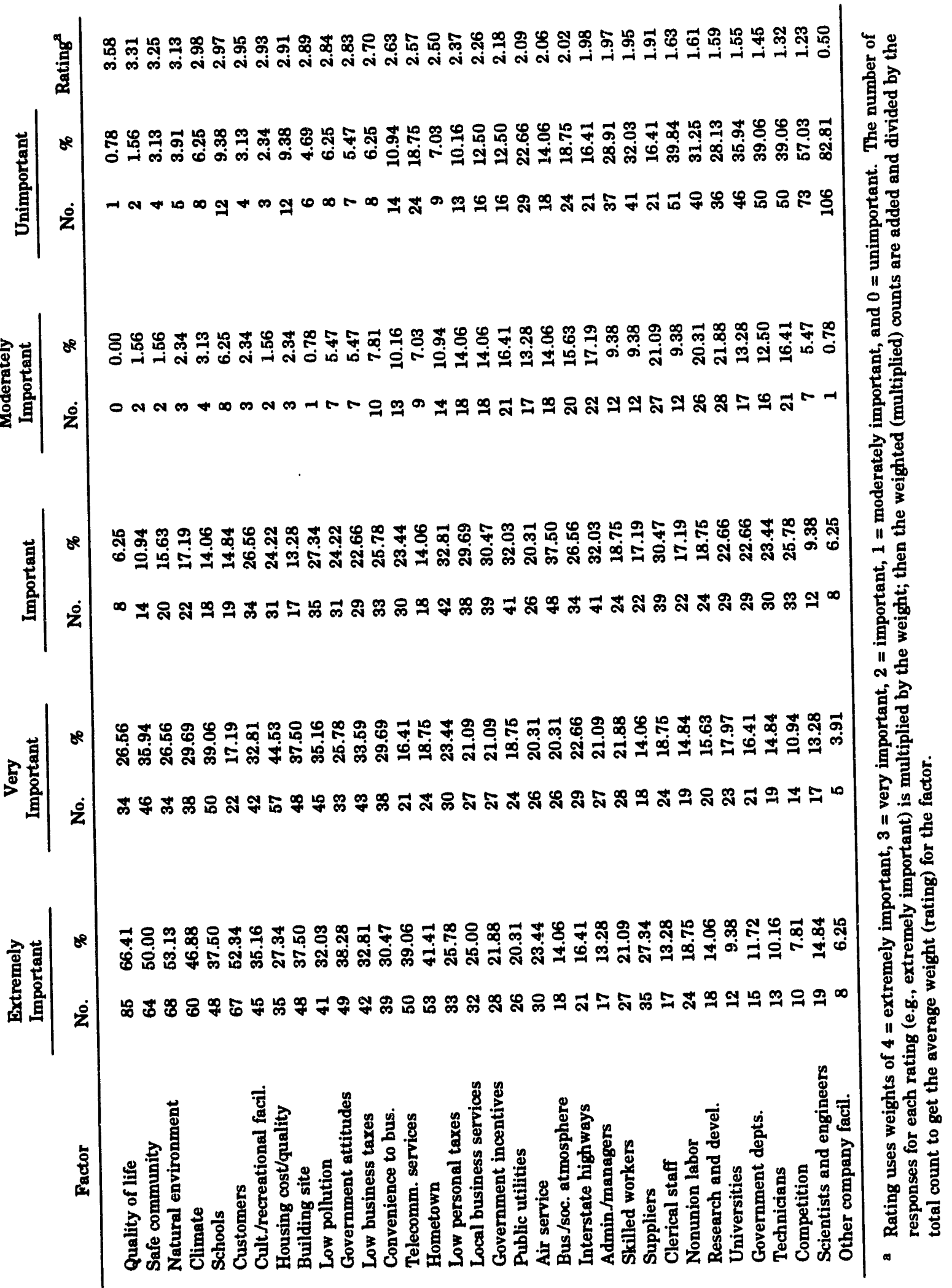




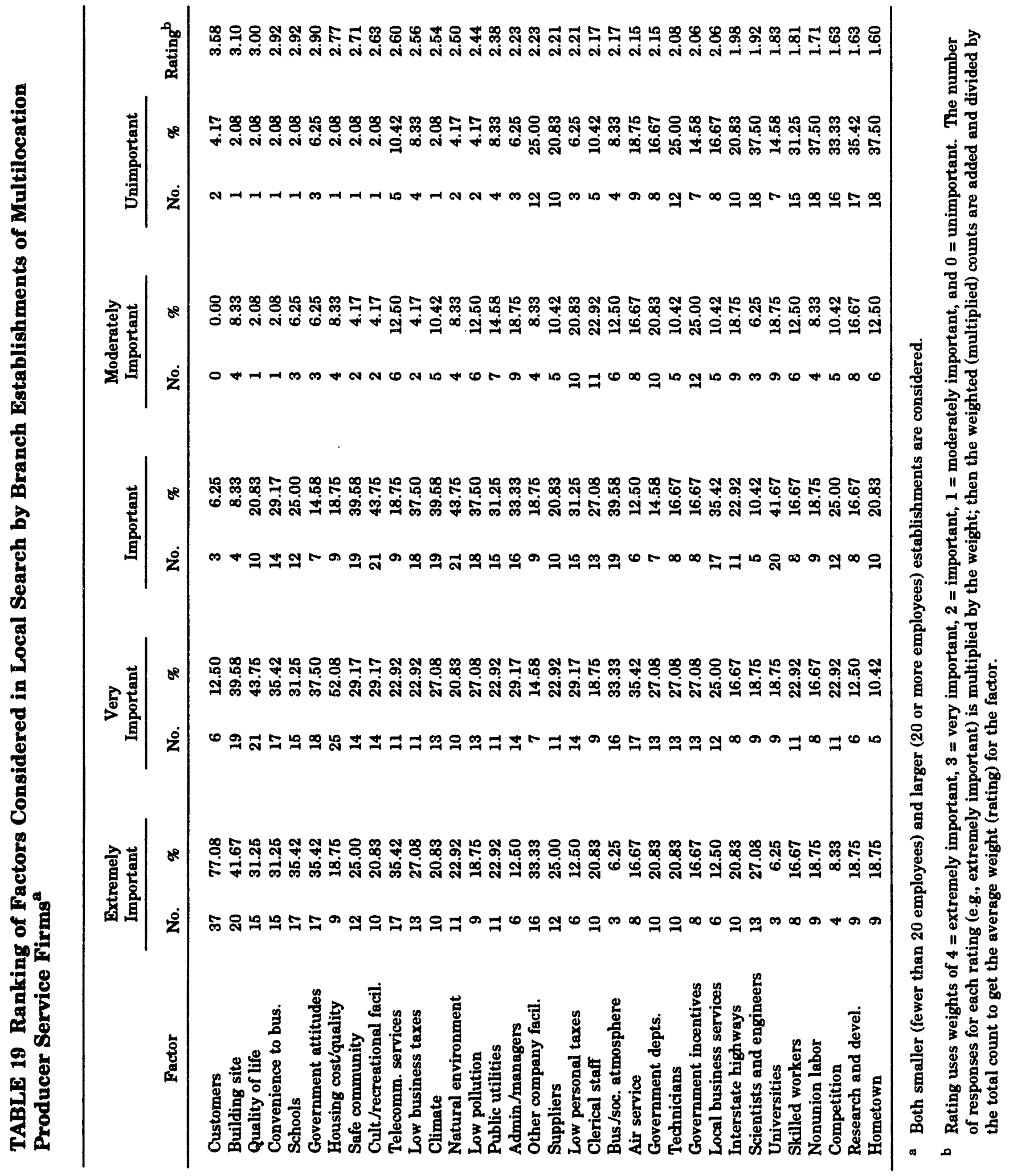




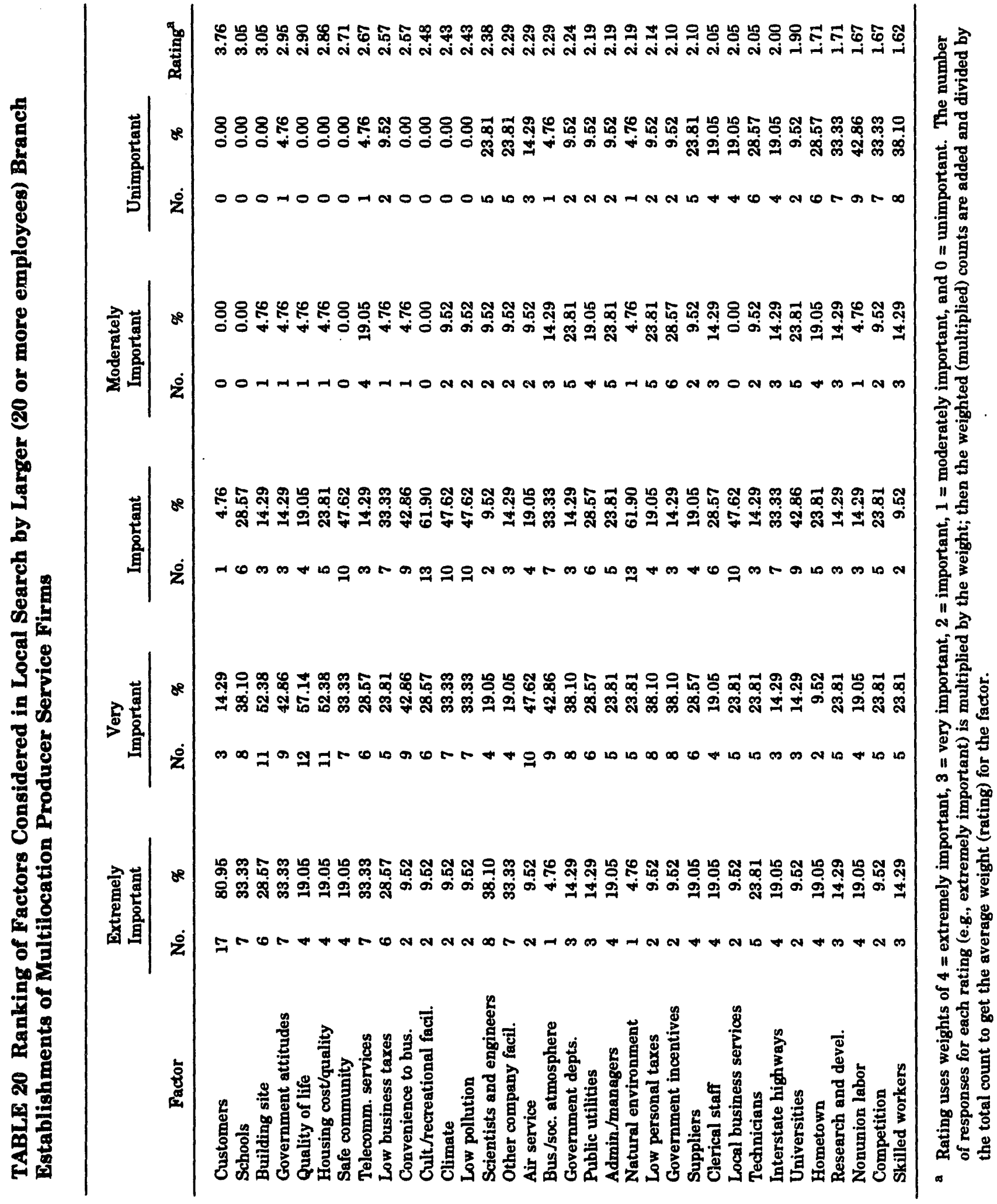


the manufacturing establishments, the interviews with the producer service establishments sought information about (1) the company, (2) reasons the location of the firm was chosen, (3) the nature of the work force, (4) whether the workers were obtained locally or from other states, (5) the importance of amenities to owners and employees, and (6) concerns over disamenities (particularly nuclear facilities).

The interviews confirmed the importance of amenities to the owners and employees of producer service establishments. A company president for a Denver advertising company said that the motto of his workers was, "We work to live," meaning that the workers took full advantage of the amenities offered in the Denver/Boulder area. Similar thoughts were expressed by representatives of other producer service establishments in Denver and Salt Lake City.

Downtown Denver is attractive to producer service establishments because of the cultural amenities and activities it offers and because it is viewed as a center of business activity. For example, a representative of one of the largest architectural firms in the country, which has an office in downtown Denver, spoke at great lengths about the theater, opera, concerts, festivals, and restaurants in the downtown area. Also mentioned was the fact that downtown Denver is energetic and relatively safe, with a mall and free downtown bus service. Although the firm had not really conducted a search for a business location when it opened its Denver office in 1973 (the San Francisco-based company won a contract for a downtown bank project requiring it to set up an office in Denver), the firm decided to locate in the downtown area because meetings with bankers, attorneys, and other clients located in the downtown area would be convenient. (This point was also made by other architectural, consulting, and advertising establishments interviewed in Denver.) The firm's representative emphasized that the amenities in downtown Denver are one reason why the company has been able to attract and retain its professional staff. Although this small office, which occupies two floors of a historic building, is cramped, the employees enjoy the ambience of the building and the breathtaking views of the mountains.

In another case, an advertising agency - a branch of a national firm with a head office in New York City - was located some distance from downtown Denver when it opened its field office in 1947. The agency is now moving to downtown Denver to be close to clients and the hub of business activity, even though it will have less office space and pay more rent. According to the manager, amenities were not an important consideration in selecting Denver as a new site for the agency. The decision to move downtown had less to do with downtown amenities than with accessibility to other businesses. This agency receives about five résumés a day from qualified people who wish to move to Colorado from the East, and almost everyone who works for the company is an "eastern transplant." As a final example, a marketing and advertising firm was located in downtown Denver until 1974, when it decided to move to the Tech Center, which is located in the southern outskirts of the city. The company moved to the Tech Center because it believed that new establishments from other states would be moving there, and it would have a better chance to gain new business if it were close to the new arrivals. 
As did the interviews with manufacturing representatives, interviews with producer service representatives revealed that the hometown factor could not be totally separated from amenity factors. Some people who had been raised in the area and later moved out emphasized that they had missed the mountains and other amenities. A case in point is illustrated by an advertising and marketing establishment in Denver. This establishment is about five years old and grew out of a New York City-based firm that formerly employed the present owner. The owner, originally from Colorado, had taken a job at an architectural firm in New York City. He later decided to leave New York City, even though he enjoyed its urban amenities, because it was too big, had too many problems, and had many other unpleasant aspects. When a Colorado high school advertised for architectural design work, he bid on the project as a representative of his New York City firm. He was awarded the contract. The winning architectural firm was required to have a local office. He then came to Denver, opened an office for the New York City firm, and hired local people to work on the project. After it ended, he started his own architectural firm in Denver. The firm now does work throughout Colorado and also out of state.

Nuclear facilities were not viewed as negative by those interviewed. The disamenities mentioned for both Denver/Boulder and Salt Lake City were air pollution and traffic congestion. Problems with youth gangs were mentioned by owners of manufacturing establishments in Salt Lake City, and one president of a producer service firm in Denver mentioned the growing problem of gangs in Aurora, Colorado. One representative of an architectural firm mentioned that the Rocky Mountain Arsenal was a problem of interest only to the inhabitants of Commerce City and had little effect on feelings toward Denver in general.

\subsubsection{Regional Search}

Table 21 summarizes the rankings of business location factors by producer service establishments responding to the regional search section of the questionnaire. Amenity factors were important at the regional level. Quality of life was ranked as the most important regional factor, with 52\% of the respondents saying it was extremely important and almost $34 \%$ calling it very important. Only three respondents said that quality of life was unimportant. Access to customers was ranked second, even though $63 \%$ of the producer service establishments said it was extremely important. Government attitudes toward business and a safe community also scored high. The other top 10 regional factors listed in order were building site (which really is not a regional factor), low business taxes, the natural environment, telecommunication services, cultural and recreational facilities, and convenience to other businesses. Other amenity factors, including schools, climate, and low pollution, were listed in the middle of the list offered for consideration. At the bottom of the list were factors such as universities, scientists and engineers, and research and development. Also of interest is the fact that nonunion labor was rated low. Although this factor was extremely important to some producer service establishments, it was unimportant to many more. 


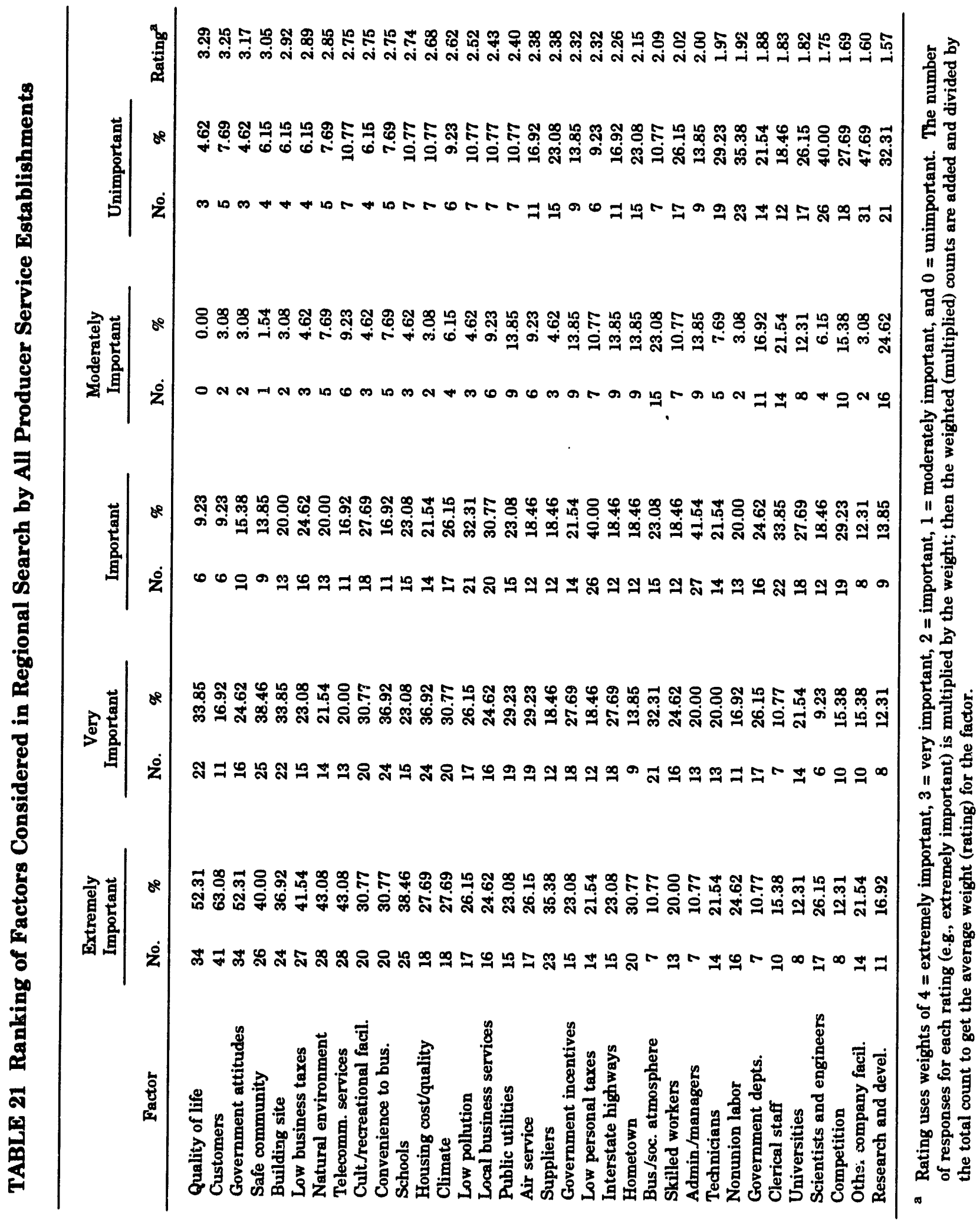




\subsubsection{Summary}

Tables 14-21 indicate that amenity factors were of great importance to all producer service establishments and of utmost importance to single-location producer service establishments. Indeed, quality of life was ranked first by single-location producer service establishments in a local search. Quality of life scored high for all categories of producer service establishments; even headquarters establishments rated quality of life as the most important factor in a local search. Quality of life also ranked first in the regional search. The principal economic factor for producer service establishments was access to customers, and economic factors were most important to branch establishments of multilocation producer service firms. Access to customers was also ranked second by all producer service establishments in a regional search. Other amenity factors ranked high across all categories of producer service establishments, with amenity factors being scored lowest by branch establishments of multilocation producer service firms. The quality of the natural environment was highly regarded by the headquarters and single-location producer service establishments in both a local and regional search. Branch establishments of multilocation producer service firms did not rank the quality of the natural environment high (thirteenth). In summary, both natural and cultural environmental amenities rated very high as factors important to producer service establishments in Colorado and Utah. 


\section{SUMMMARY OF FINDINGS AND IMPLICATIONS FOR HIGH-LEVEL WASTE STORAGE AND DISPOSAL PROGRAMS}

\subsection{SUMMARY}

Findings from surveys and on-site interviews of manufacturing and producer service establishments in Colorado and Utah point to the increasing importance of amenities (and disamenities) in decisions to site or relocate certain types of businesses or business activities. Therefore, any perceptions of risk (a disamenity) associated with nuclear waste facilities would seem to have the potential to affect decisions made being by firms on whether to site a variety of different business establishments in host communities or relocate them elsewhere. The findings also show, however, that the extent to which decisions made to site or relocate specific business establishments are likely to be affected depends closely on a number of factors.

The first factor is the category of business activity in which the establishment is engaged. Does it manufacture products or provide business services? In the surveys, producer service establishments ranked amenity factors higher than did manufacturing establishments. Therefore, producer service establishments in potential host locations would seem more likely to be affected by any perceptions of risk that might occur with the siting of a nuclear waste facility than would manufacturing establishments.

The second factor is the size of the establishment. Is it large or small in terms of total full-time employment? For manufacturing establishments, amenity factors were ranked higher by smaller establishments than larger establishments. For establishments providing producer services, quality of life was the highest-ranked factor by both larger and smaller establishments. Smaller manufacturing establishments and both larger and smaller producer service establishments in potential host locations would therefore seem more likely to be affected by any perceptions of risk that might occur with the siting of a nuclear waste facility than would larger manufacturing establishments.

The third factor to be considered is the type of establishment. Is it a single-location establishment, branch establishment, or headquarters establishment? For manufacturing establishments, amenity faitors were ranked higher by single-location establishments than branch establishments. For establishments providing producer services, quality of life was the highest-ranked factor by single-location and headquarters establishments. Single-location manufacturing and producer service establishments and headquarters establishments in potential host locations would therefore seem more likely to be affected by any perceptions of risk that might occur with the siting of a nuclear waste facility than would manufacturing and producer service branch establishments.

The fourth factor is the importance of hometown considerations in the decision to locate a new business establishment or expand an existing establishment in a potential host community. Survey results show that the hometown factor - which includes natural and 
cultural amenities (quality of the natural environment, safe community, climate, schools, cultural and recreational facilities, and housing quality) offered in the location in which the entrepreneur is residing - were found to be important to smaller manufacturing establishments and, in particular, smaller producer service establishments. It may be difficult to predict how important any perceptions of risk that might occur with the siting of a nuclear waste facility would be to an establishment operated by an entrepreneur in his or her hometown. In some situations, the preference for hometown amenities may offset any perceptions of risk that may arise. Whether or not any risk perceptions are offset is likely to depend on the particular amenities offered by each community. It is also likely to depend on the extent to which these amenities are offered by other similar locations at which no nuclear waste facility exists or is planned. Other factors that could also be important in offsetting risk perceptions are (1) the level of access to existing markets and to business contacts that is offered at other locations under consideration and (2) the extent of competition with the firm's product or service there is at other locations being considered.

Amenities also indirectly affect location decisions through the influence they have on the location choices of key technical and scientific personnel. Some establishments require access to high-quality support staff. The quality of local education is an important consideration to individuals choosing an area in which to live and work; it also provides an indication of the quality of support from the higher education system that will be available to a firm. Survey results showed that quality of education was an amenity factor rated among the highest by all categories of manufacturing establishments. The extent to which establishments that rely on a local supply of key technical and support staff and a high-quality local education system would be affected by perceptions of risk that might occur with the siting of a nuclear waste facility would depend on two factors: (1) how any perceptions of risk held by key personnel in the establishments to be located in potential host locations would influence their location preferences and (2) how any perceptions of risk held by those involved in the higher education system would affect the evaluation of present locations.

The importance of amenities also seems to vary according to the extent of the search for a new location. Multilocation manufacturing and producer service firms tend to conduct a wide regional search - a search of a variety of locations in different regions of the country - before deciding to site an establishment in a particular location. Single-location establishments, however, tend to consider only a handful of locations before deciding on a particular one (i.e., they conduct a local search). The survey results discussed up to this point in this report are for local searches. Survey results also showed that in a regional search, amenity factors were more important to producer service establishments than manufacturing establishments. These findings indicate that any perceptions of risk associated with nuclear waste facilities in a potential host location would influence a producer service firm conducting a regional search more than a manufacturing firm conducting a regional search.

Although the evidence presented in this report shows how important amenities are to various business activities in Colorado and Utah, these findings do not necessarily apply to all locations. Each location is unique with respect to the level of amenities it offers, the 
way in which the amenities are perceived by the local community, and the way in which they are perceived by those likely to consider that location as a site for new or expanded business activities. Colorado and Utah are very rich in amenities, and the Denver/Boulder and Salt Lake City areas have an abundance of natural and cultural amenities and quality-of-life attributes that are difficult to match anywhere else. In addition, interviews revealed that many business owners in these locations were well educated or had close ties to the University of Colorado or University of Utah.

The findings of this report do, however, provide OCRWM with important information on how businesses engaged in different activities rate the level of amenities in a community and, consequently, on how important any risk perceptions associated with nuclear waste facilities are to businesses that might choose the host community as a location for new or expanded business establishment.

\subsection{IMPLICATIONS}

This report compares the importance of amenity and nonamenity factors that are considered by all firms choosing a location for an establishment. The results of the surveys skow that while amenity factors were found to be important for a range of business activities, other key nonamenity factors in an area must also be favorable before a firm is likely to choose a location there for a new or expanded business establishment. Therefore, when a location for a nuclear waste facility is being chosen, the decision maker needs to carefully evaluate the economic characteristics of each potential location in addition to the level of amenities it offers. Only then can the decision maker predict the effect that any risk perceptions associated with the facility might have on decisions being made by firms to locate business activities in the local economy.

To provide OCRWM decision makers with information on the potential impacts that changes in the level of amenities and any risk perceptions associated with nuclear waste facilities might have on business location decisions, this section of the report applies the survey findings to the Las Vegas region (the only candidate host for the permanent nuclear waste repository at Yucca Mountain) and to rural areas likely to volunteer to host temporary nuclear waste storage (MRS) facilities. The importance of amenity and nonamenity factors with respect to the location of existing and potential new business activities is likely to be very different in the Las Vegas area than it is in rural areas, as is the impact of any risk perceptions associated with nuclear waste facilities. These differences relate not only to the type of amenities available (those offered by Las Vegas compared with those offered by rural locations) but also to the characteristics of the local economy (Las Vegas versus rural locations) and the influence they have on which business activities are likely to locate in either area.

In recent years, the economy of the Las Vegas metropolitan area has begun to diversify from the gaming and hospitality industries, although the recreational opportunities offered by these and other related business activities in the area still draw new establishments and the key scientific and technical personnel employed at many of these 
establishments. This area can now support and attract a much wider range of business activities than before. Changes in the level of amenities or any perceptions of risk that might develop in the Las Vegas area as a result of the repository program therefore have the potential to affect a wide range of business activities.

Survey results show that amenities are often very important to headquarters establishments and establishments involved in other business activities requiring high-order executive and white-collar personnel (e.g., finance, insurance, legal, services, advertising, and research and development activities). Establishments involved in these activities are usually drawn to the type of amenities found in larger metropolitan areas, such as those now developing in the Las Vegas area. Other factors important to headquarters facilities (e.g., the need to minimize costs associated with face-to-face contacts between employees and clients, customers, or other key personnel in the firm) have also recently begun to cause locations other than the traditional ones of New York, Chicago, Los Angeles, and San Francisco to be favored.

Smaller firms that market specialized business services also often locate establishments in larger urban areas, in order to be close to headquarters establishments of other firms and to the types of amenities that might attract new headquarters establishments. These smaller firms might consider locating in the Las Vegas area, and they might also be affected by changes in the level of amenities Las Vegas offers. In particular, some of these smaller specialized producer service firms (e.g., those that provide consulting services in engineering, management, or computing or offer architectural, marketing, or financial services) might be able to compete from locations in the Las Vegas area, because of recent improvements in conventional mail and telecommunications there coupled with these firms' increased use of contact networks to gain access to potential customers located in larger metropolitan areas like New York, Chicago, Los Angeles, and San Francisco.

Las Vegas's environmental amenities - particularly its recreational amenities - and its lack of disamenities associated with larger urban centers might attract some firms because they feel the area either already has, or is likely to attract, key scientific and technical personnel from elsewhere. In these cases, the amenities offered by the Las Vegas area might indirectly influence the decision of some firms with respect to locating particular types of business establishments. For example, the quality of education influenced the location decisions of manufacturing establishments that chose Colorado and Utah. In addition, Las Vegas's amenities might influence the location decisions being made by smaller producer service establishments and specialized manufacturing establishments, which might be started in Las Vegas by people previously employed by larger firms located elsewhere.

Although survey results show that cultural and environmental amenities are much more likely to influence the location of business service activities than manufacturing activities, amenities can still, nonetheless, indirectly influence the location decisions of larger manufacturing firms that are deciding where to locate branch establishments that manufacture products in their early stages of development. These types of manufacturing branch establishments need to be close to headquarters and research and development 
establishments that provide initial support. Las Vegas has been successful in attracting a small number of manufacturing branch establishments that engage in activities of this type. Thus, changes in the level of amenities offered by Las Vegas could indirectly and adversely affect the location decisions being made for these establishments, because of the importance of amenities to headquarters and research and development establishments.

When production becomes routine and does not require substantial scientific and technical backup, manufacturing activities can be undertaken by branch establishments, for which the cost and availability of production labor are the prime location factors. Las Vegas's lower cost of doing business (compared with the Los Angeles area) and its proximity to markets in southern California and southern Arizona may draw branch establishments in the near future. Survey results show that amenity factors are much less likely to be important to manufacturing branch establishments engaged in routine production activities, primarily because these establishments have few positions for executive, scientific, and technical staff. The same factors that are important for locating routine production functions are also important for locating routine office functions in both manufacturing firms and producer service firms. Therefore, any branch establishments of manufacturing and business service firms that have been attracted to the Las Vegas area will probably not be affected by any risk perceptions associated with the Yucca Mountain project.

Although smaller single-location establishments are not as important as larger multilocation firms in terms of total employment, they do dominate the Las Vegas economy in terms of their absolute number. Smaller single-location establishment firms are also likely to be an important part of the economies of small rural communities, which are the locations likely to volunteer to host temporary nuclear waste (MRS) facilities. Survey results indicate that changes in amenities and any risk perceptions that arise as a result of the siting of a nuclear waste facility are likely to be more important to smaller manufacturing and producer service firms, primarily because the individual preferences of the entrepreneur (particularly knowledge of local markets and suppliers and preference for hometown locations) are often the most important factor in the location decision of smaller firms. For these firms, in particular, local cultural amenities may provide a basis for a location decision and may be a more important factor than amenities in the natural environment. Local recreational amenities may also enhance the attractiveness of both Las Vegas and the rural communities as business locations to local entrepreneurs.

As has been suggested, the likelihood that an entrepreneur will move to another area or remain in an existing location if a nuclear waste facility is sited nearby depends on the extent to which hometown amenities are offered in other similar locations that have no existing or planned nuclear waste facility. It also depends on the level of access to existing markets and to business contacts offered by other locations, and it depends on how much competition with the firm's product or service there is at any other locations the firm is considering as a place to site or relocate an establishment.

The Las Vegas economy has developed the potential to attract a range of business activities on the basis of its various amenity and nonamenity factors. The rural nature of 
locations likely to volunteer to host MRS facilities, however, limits the range of business activities likely to locate in these communities. Smaller single-location manufacturing and producer service establishments are likely to continue to be the main establishments found in these communities. As has been suggested, hrmetown factors are often important when a change in the level of amenities or any perceptions of risk that may arise with the siting of a nuclear waste facility may influence the decision to remain in a small community or choose another location in a similar community elsewhere. Market considerations, such as the extent of the firm's contact network and the level of product competition in possible alternate locations, are also important and may not favor a move to another location for many smaller single-location firms.

Larger firms might also locate establishments engaged in manufacturing or toutine office functions in rural areas. Survey results show that amenities are not usually considered in decisions on where to locate these types of establishments. The location choice for establishments engaged in these activities is also unlikely to be affected by any risk perceptions that arise from the siting of a nuclear waste facility. Even though amenities are important to the people who choose locations for manufacturing or producer service branch establishments, these decision makers do not themselves work in the rural areas but rather in corporate headquarters in larger metropolitan areas. It is unlikely that any perceptions of risk that develop in the community in which branch facilities are located would affect a choice of whether to continue to do business or locate a new establishment in a community hosting a nuclear waste facility.

The results of the surveys of manufacturing and producer service establishments in Colorado and Utah show that amenities are a significant factor considered in their evaluations of a location as a place to do business. This finding suggests that undesirable changes in the quality of amsnities and the development of any perceived risk that might result from the siting of a nuclear waste facility would have predictable effects on business location behavior. These undesirable changes and perceptions would be probably degrade an area's image as a good business location and possibly hinder future business development opportunities in that area. As has been suggested for Las Vegas and for smaller rural communities, however, the actual impact of any perceived risk that may arise as a result of siting a nuclear waste facility on business location decisions is likely to vary considerably, depending on (1) the economic characteristics of the location under consideration, and therefore the type of business and business activity that is or might be attracted to that location, and (2) the importance of amenities to each type of business activity, and therefore each business's sensitivity to any perceived risk that might develop as a result of the siting of a nuclear waste facility. These factors must be considered in any estimations of the likely impacts from siting a nuclear waste facility on business location decisions and in any attempts to mitigate or compensate for these impacts in communities and regions that might become hosts to a nuclear waste facility. 


\section{REFERENCES}

Allison, T., 1991, Socioeconomic Assessment Guidance Report: Determining the Effects of Amenity Characteristics on Business Location Decisions, ANL/EAIS/TM-85, Argonne National Laboratory, Argonne, Ill., Feb.

Allison, T., and F. Calzonetti, 1990, The Role of Amenities and Other Factors in Influencing the Location of Nonmanufacturing Industry in the United States, ANL/EAIS/TM-41, Argonne National Laboratory, Argonne, Ill., July.

Ballard, S.C., and T.E. James (editors), 1983, Ti.e Future of the Sunbelt, Praeger, New York, N.Y.

Burgess, J.A., 1982, "Selling Places: Environmental Images for the Executive," Regional Studies 16:1-17.

Burns, L., and W.N. Pang, 1977, "Big Business in the Big City: Corporate Headquarters and the CBD," Urban Affairs Quarterly 12:533-544.

Greenhut, M.L., 1956, Plant Location in Theory and Practice, University of North Carolina Press, Chapel Hill, N.C.

Hall, P., et al., 1987, Western Sunrise: The Genesis and Growth of Britain's Major High-Tech Corridor, Allen Unwin, Boston, Mass.

Hart, J.F., 1988, "Small Towns and Manufacturing," The Geographical Review 78:272-287, July.

Ihlanfeldt, K., and M. Raper, 1990, "The Intrametropolitan Location of New Office Firms," Land Economics 66:182-198.

Kale, S.R., and R.E. Lonsdale, 1979, "Factors Encouraging and Discouraging the Location of Industries in Non-Metropolitan Areas," in Non-Metropolitan Industrialization, R.E. Lonsdale and H.L. Seyler (editors), John Wiley \& Sons, Inc., New York, N.Y.

Keeble, D.E., 1980, "Industrial Decline, Regional Policy and the Urban-Rural Manufacturing Shift in the U.K.," Environment and Planning A 12:954-962.

Keeble, D.E., 1989, "High-Technology Industry and Regional Development in Britain: The Case of the Cambridge Phenomenon," Environment and Planning C 7:153-172.

Ley, D., 1985, "Downtown or the Suburbs? A Comparative Study of Two Vancouver Head Offices," The Canadian Geographer 29:30-43.

Malecki, E., 1989, "What about People in High Technology? Some Research and Policy Considerations," Growth and Change 20:67-79. 
Markusen, A., et al., 1986, High-Tech America, Allen Unwin, Boston, Mass.

McGregor, B.D. et al., 1986, "The Development of High Technology in the Newbury District," Regional Studies 20:433-448.

McLaughlin, G.E., and S. Robock, 1949, Why Industry Moves South, National Planning Association, Washington, D.C.

Moss, M., and A. Dunau, 1986, The Location of Back Offices: Emerging Trends and Development Patterns, New York University, Real Estate Institute, New York, N.Y.

Pacione, M., 1982, "Space Preferences, Locational Decisions, and the Dispersal of Civil Servants from London," Environment and Planning A 14:323-333.

Plaut, T.R., and J.E. Pluta, 1983, "Business Climate, Taxes and Expenditures and State Industrial Growth in the U.S.," Southern Economic Journal 50:99-119.

Raitz, K., 1988, "Advantages of Place as Perceived by Sunbelt Promoters," Growth and Change 19:14-29.

Reynolds, P., and S. Freeman, 1987, 1986 Pennsylvania New Firm Survey, Appalachian Regional Commission, Washington, D.C.

Reynolds, P., and B. Miller, 1987, 1987 Minnesota New Firm Survey, University of Minnesota, Hubert Humphrey Center, Minneapolis, Minn.

Rhodes, J., and A. Kan, 1971, Office of Dispersal and Regional Policy, Cambridge University Press, Cambridge, Great Britain.

Schmenner, R.W., 1982, Making Business Location Decisions, Prentice Hall, Inc., Englewood Cliffs, N.J.

Smith, D., 1971, Industrial Location, John Wiley \& Sons, Inc., New York, N.Y.

Spooner, D., 1973, "Industrial Movement and the Rural Periphery: The Case of Devon and Cornwall," Regional Studies 6:197-215.

Stafford, H., 1974, "The Anatomy of the Location Decision: Content Analysis of Case Studies," in Spatial Perspectives on Industrial Organization and Decisionmaking, F.E.I. Hamilton (editor), John Wiley \& Sons, Inc., New York, N.Y.

Urban Systems Research and Engineering, Inc., 1974, Small City Manufacturing Growth, U.S. Department of Health, Education and Welfare, Washington, D.C.

Wheat, L.F., 1973, Regional Growth and Industrial Location, Lexington Books, Lexington, Mass. 
Wheat, L.F., 1986, "The Determinants of 1963-77 Regional Manufacturing Growth: Why the South and West Grow," Journal of Regional Science 26:635-658. 
55

APPENDIX:

MANUFACTURING ESTABLISHMENT SURVEY QUESTIONNAIRE 


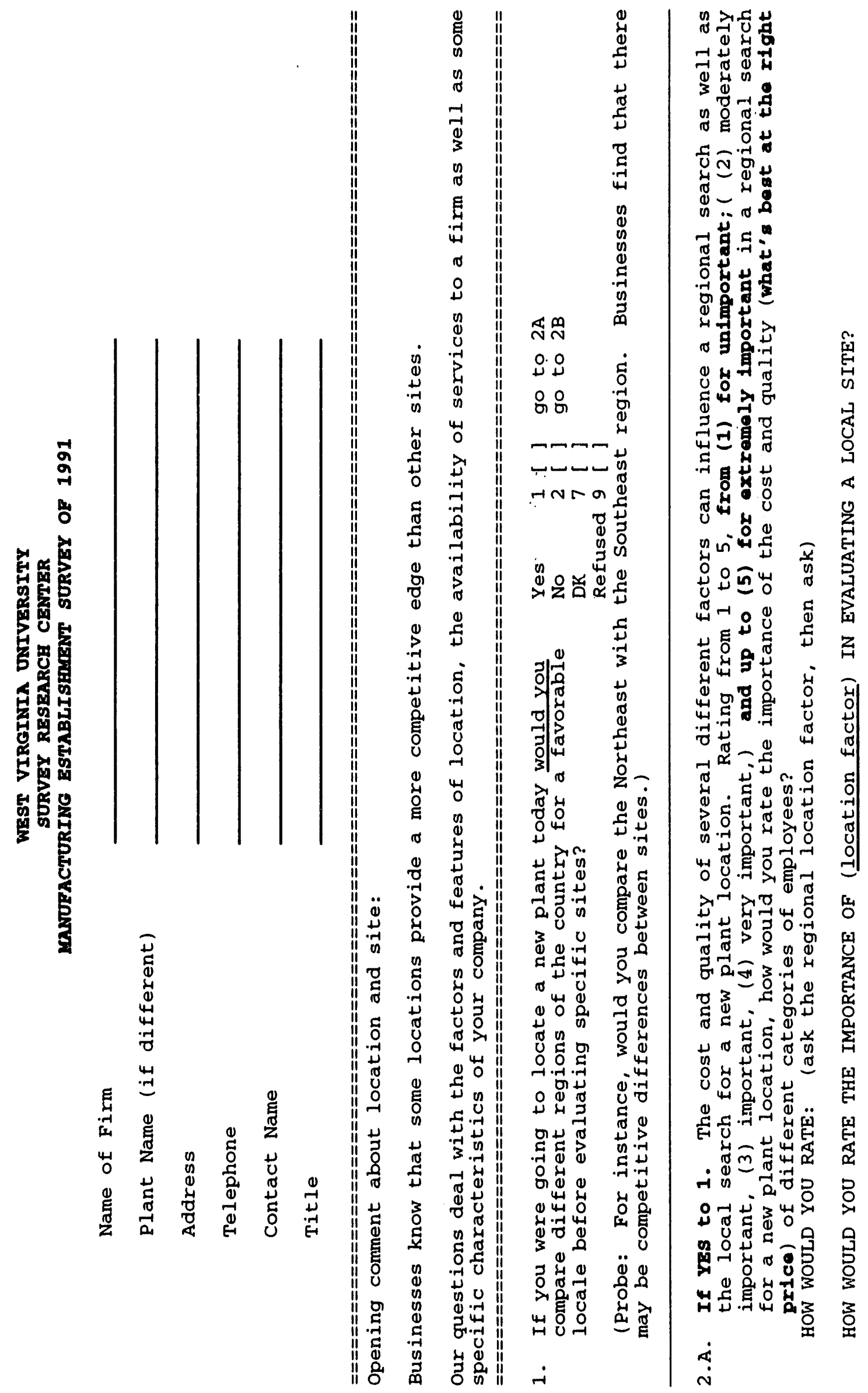




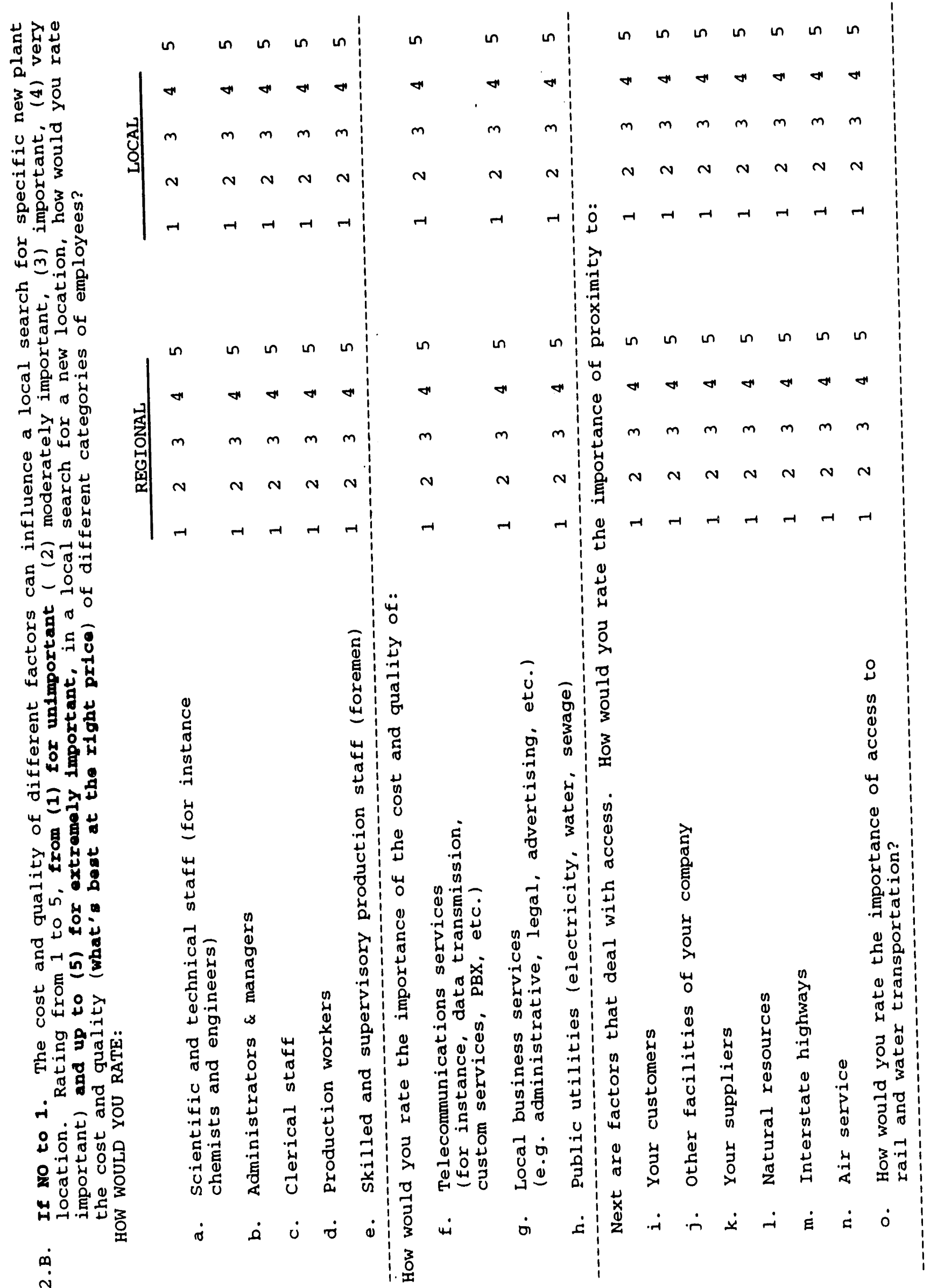




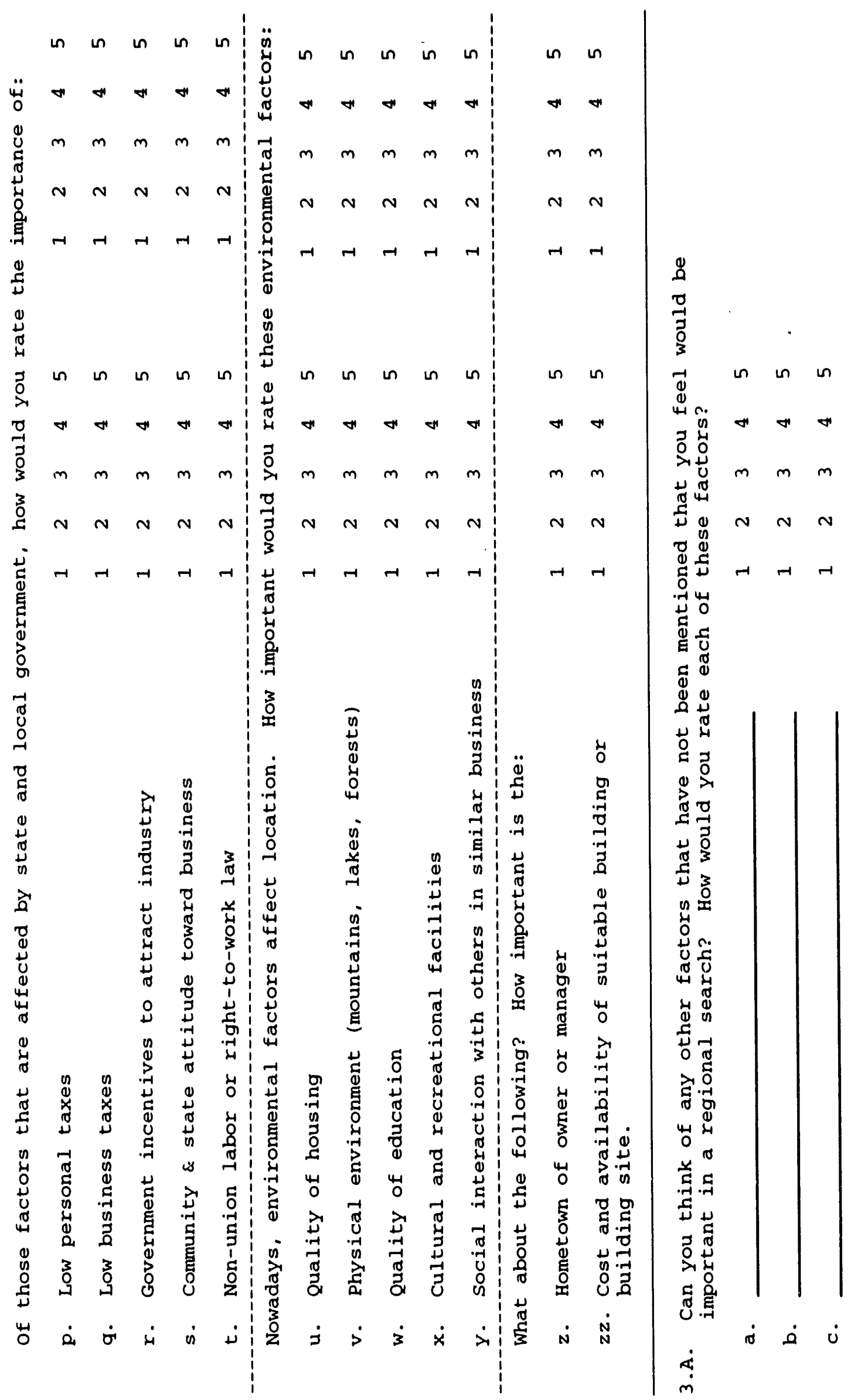




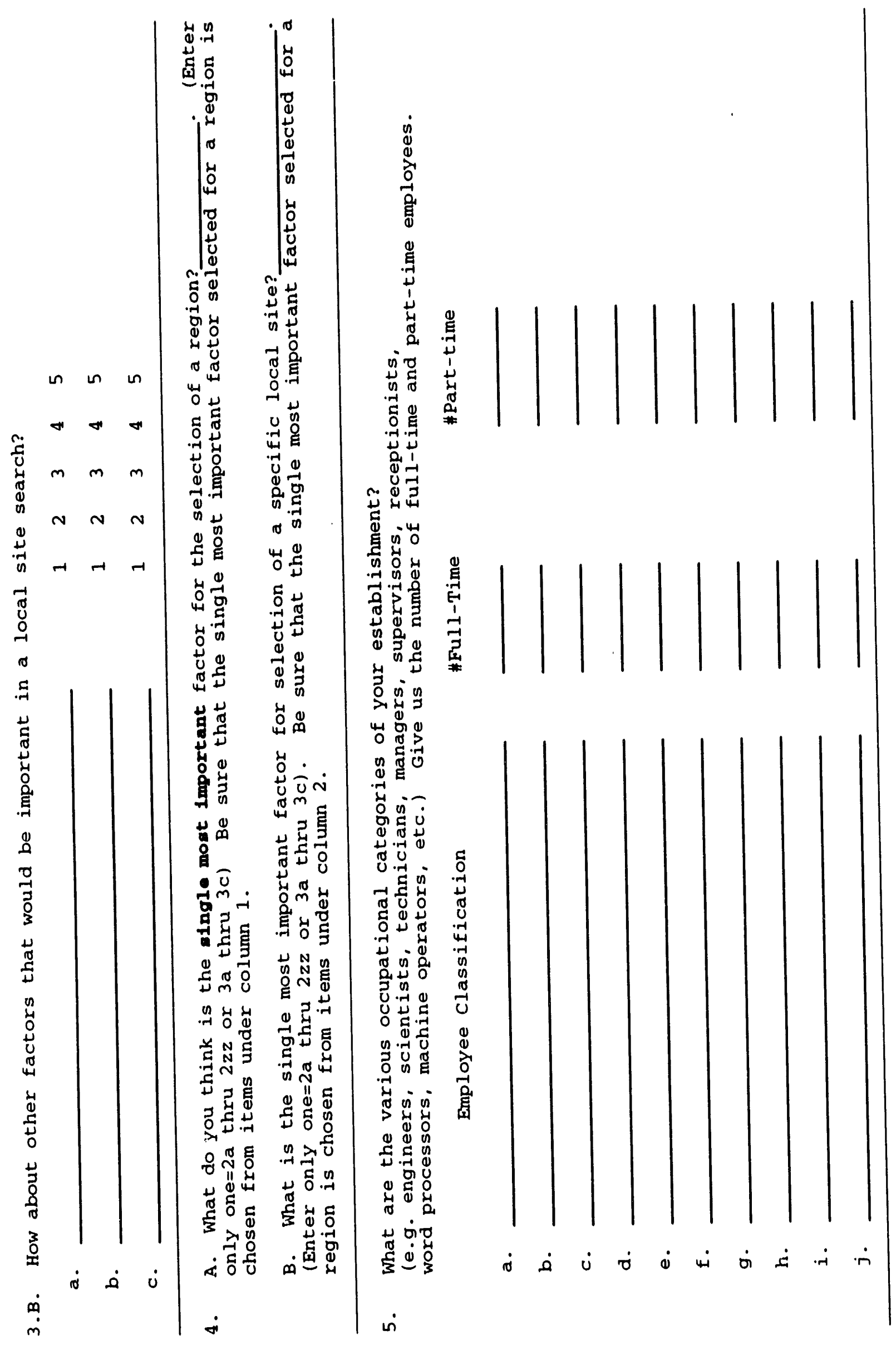




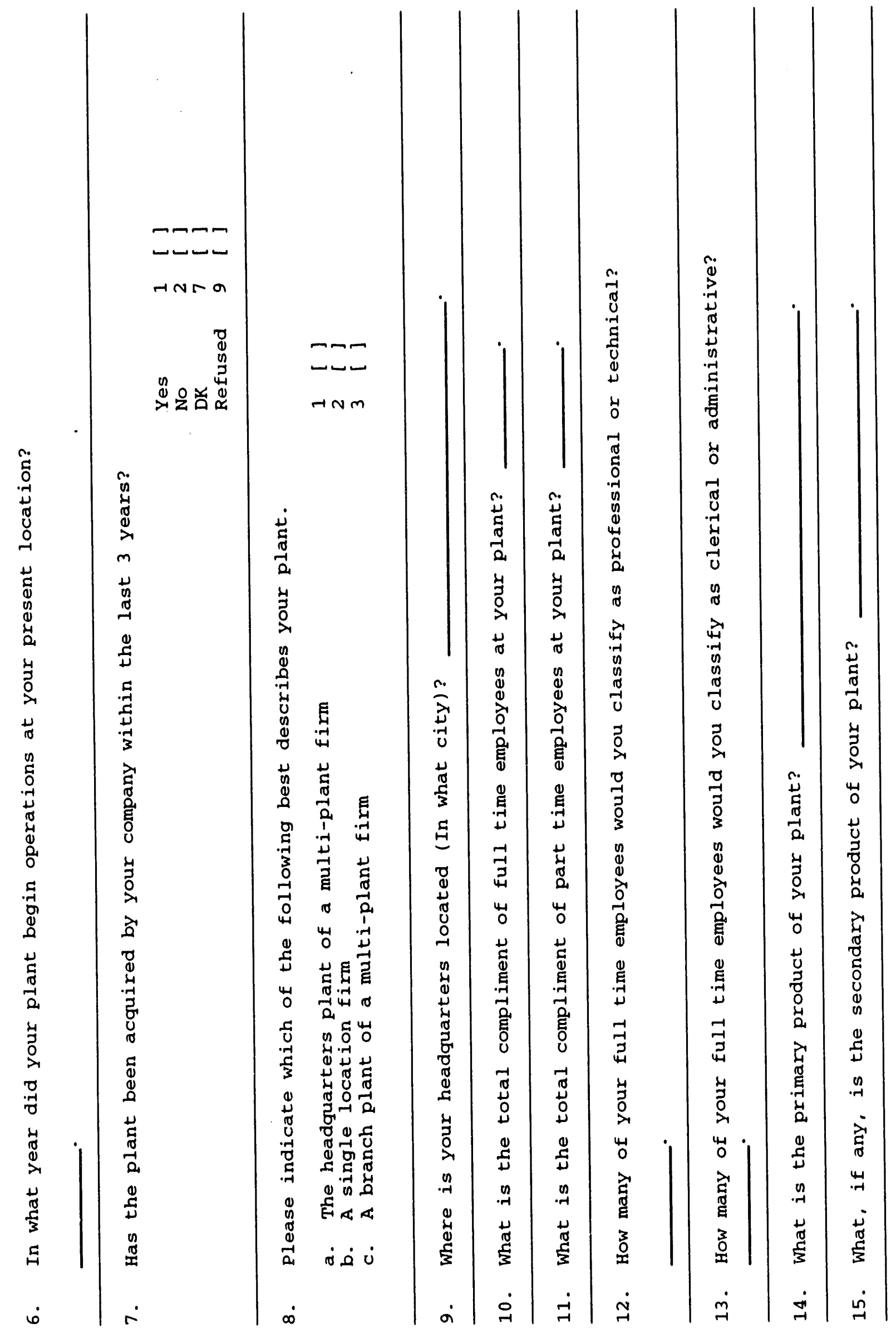




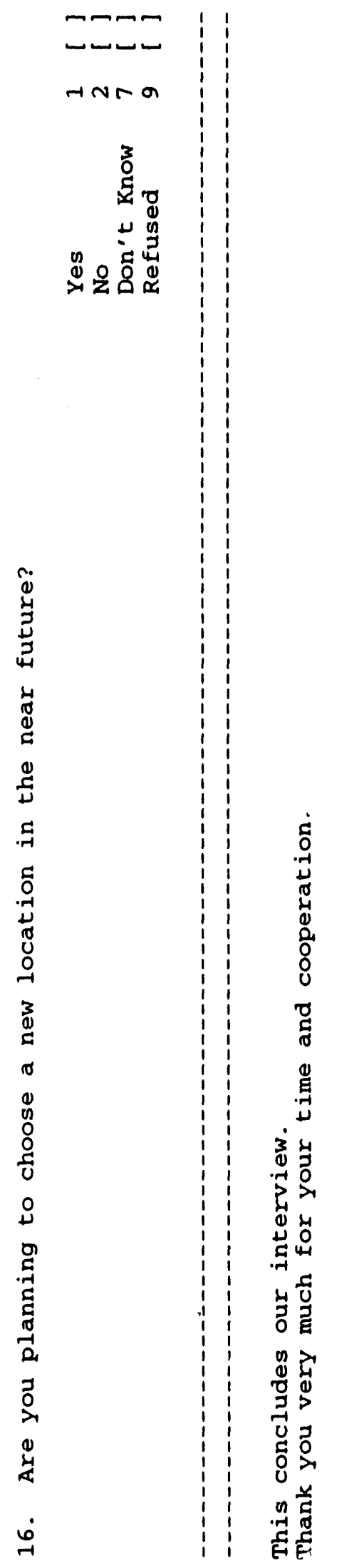




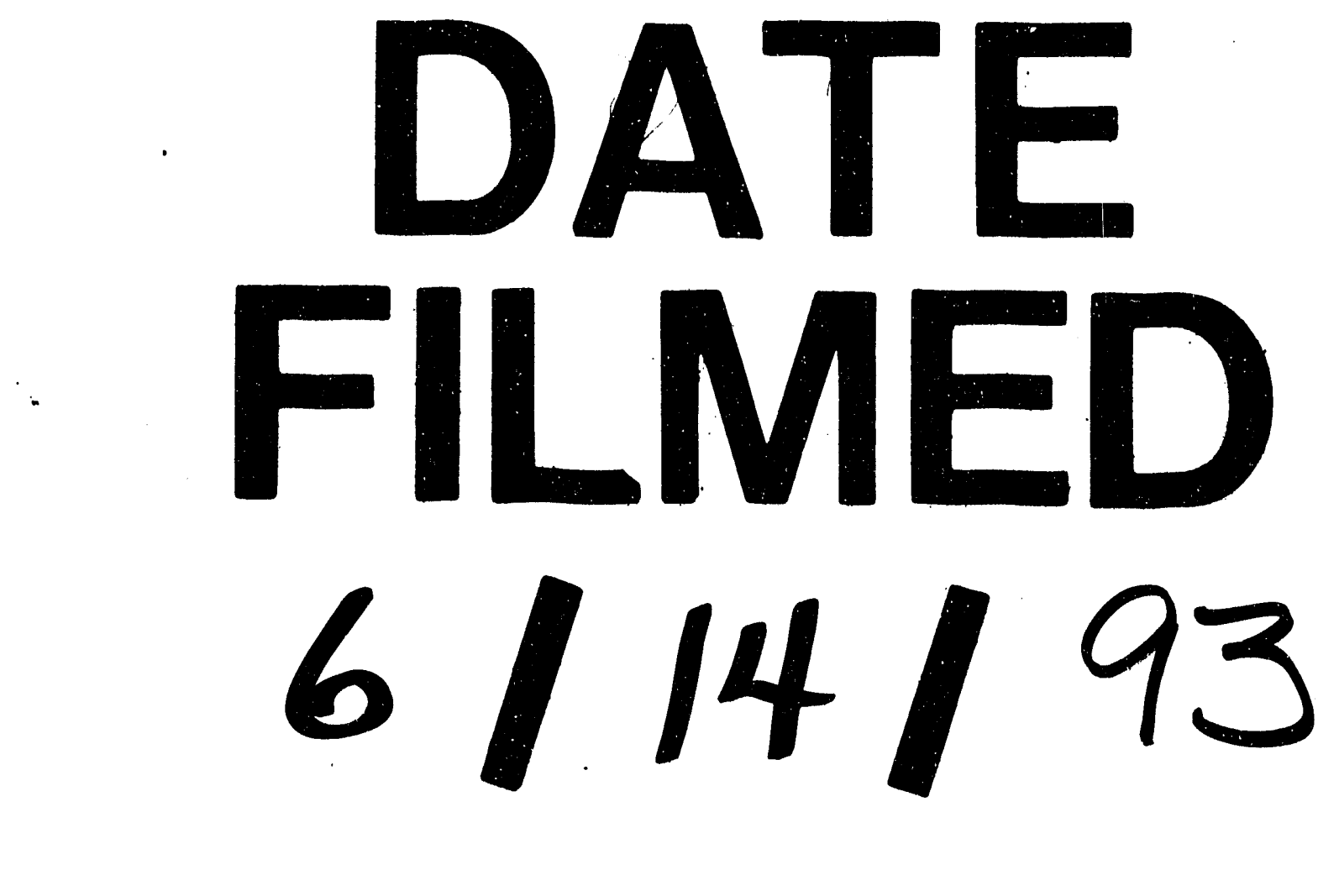

